\title{
BARRIERS TO ADOPTION OF METHANE DIGESTER TECHNOLOGY ON CALIFORNIA DAIRIES
}

\author{
A Thesis \\ presented to \\ the Faculty of California Polytechnic State University, \\ San Luis Obispo
}

In Partial Fulfillment

of the Requirements for the Degree

Master of Science in Agribusiness

by

Desireé Lee Libarle

December 2014 
(C) 2014

Desireé Lee Libarle

ALL RIGHTS RESERVED 


\section{COMMITTEE MEMBERSHIP}

TITLE:

Barriers to Adoption of Methane Digester Technology on California Dairies

AUTHOR:

Desireé Lee Libarle

DATE SUBMITTED:

December 2014

COMMITTEE CHAIR:

Wayne Howard, PhD

Professor of Agribusiness

COMMITTEE MEMBER: James Ahern, PhD

Professor of Agribusiness

COMMITTEE MEMBER: $\quad$ Bruce Golden, PhD

Professor of Dairy Science 


\begin{abstract}
Barriers to Adoption of Methane Digester Technology on California Dairies

Desireé Lee Libarle
\end{abstract}

The goal of this research was to analyze the barriers to adoption of methane digesters on California dairies. Methane digesters have long existed as a technology in the dairy industry, both in the United States and abroad. Much research has been done to attest to the viability and economic sustainability of methane digesters; however in 2014, there were 26 dairies in California that have methane digesters installed, and of these, only 17 of those were still in operation, according to the USEPA AgStar Anaerobic Digester Database. Hence, the question remains, as to why this technology has not been widely adopted at the farm level.

Of the 12 interviews conducted, four were with dairies which housed operational digesters. Four more assessed dairies where digesters were no longer operational and an additional four were conducted with dairies that were considering implementing this technology. Results from the interviews were analyzed using qualitative methods to categorize and interpret the textual data collected.

The study found a low level of understanding or competence in the amount of training and technical support necessary for dairy farmers in the installation, operation and long-term maintenance of methane digesters. The study identified initial costs of implementing combined with low negotiated energy prices and changing emissions regulations were among the main reasons for a lack of adoption in California. In addition, the study found geographic location and changing emissions regulations were main factors in the success or failure of this technology. Furthermore, the studies observed those dairies with a third party management contract were the most successful with their digester systems. Most participants of this study view the widespread adoption at the farm level as unlikely at this time. 


\section{ACKNOWLEDGMENTS}

Thanks to the Agribusiness Department at California State University, San Luis Obispo, for all their help and support in the completion of this study.

Thanks to my committee chair, Dr. Wayne Howard, who gave the idea, inspiration and unfailing support for this most interesting and progressive topic.

Thanks to Dr. Jim Ahern and Dr. Bruce Golden, for continuing to offer ideas, insides and constructive analysis of the issues surrounding this topic.

Thanks to my family and friends for their support and enthusiasm over the years in aiding me along the path to completion, and to my very understanding and gracious husband.

Special thanks to Dr. Barbara Wynne Sorenson, Department of School Counseling and School Psychology, Azusa Pacific University, for her unflagging support and guidance in all things. 


\section{TABLE OF CONTENTS}

Page

LIST OF TABLES .................................................................................. viii

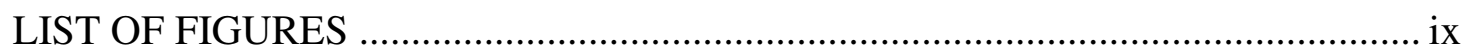

CHAPTER

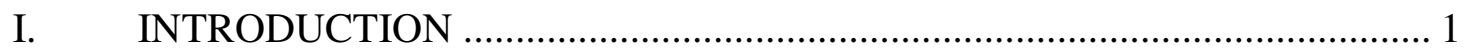

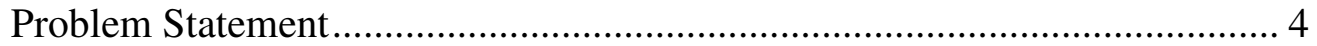

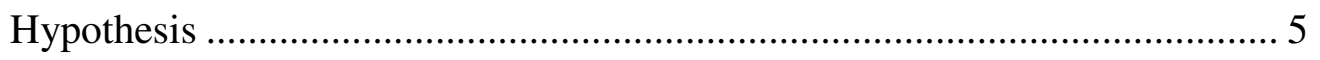

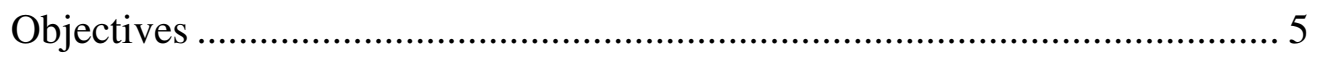

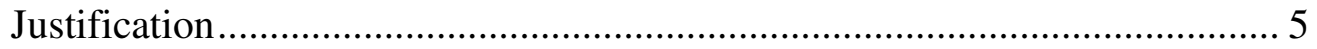

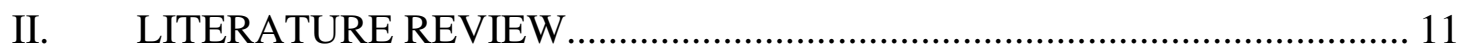

Methane Digestion Technology ........................................................... 11

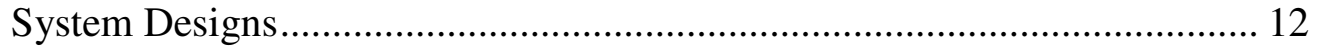

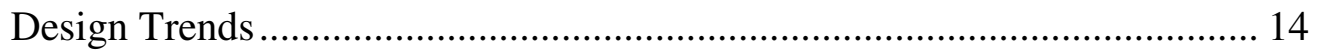

Dairy Waste Collection and Removal .................................................. 16

Factors Influencing Efficiency ......................................................... 16

U.S. Policies in Support of Methane Digesters ......................................... 18

Opportunities for Methane Digesters....................................................... 21

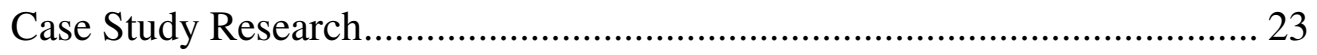

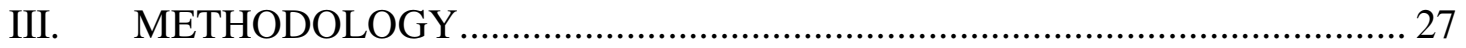

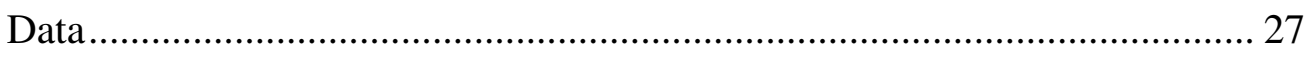

Assumptions and Limitations ........................................................... 33

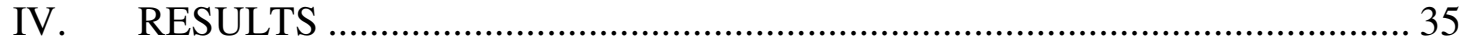

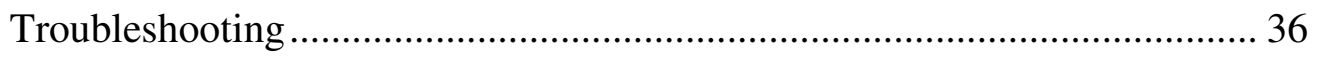

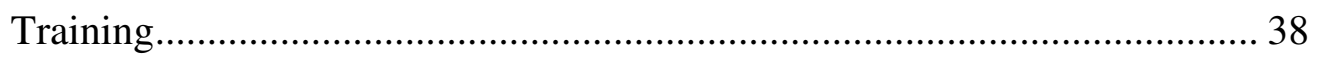

Operation and Maintenance Issues ........................................................ 39

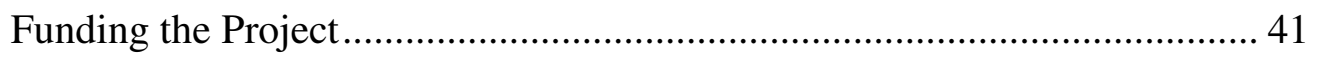

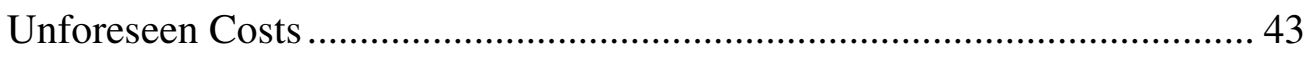

Time Constraints and Commitments ........................................................ 47 
Motivation for Adoption................................................................... 49

Issues Related to Expectations and Performance ....................................... 51

Issues for Considering Adoption ........................................................ 54

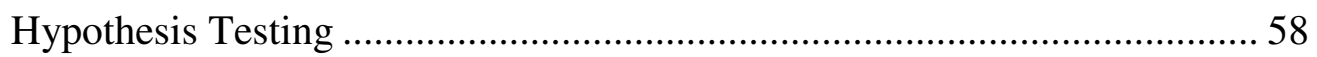

V. SUMMARY, CONCLUSIONS AND RECOMMENDATIONS ................... 60

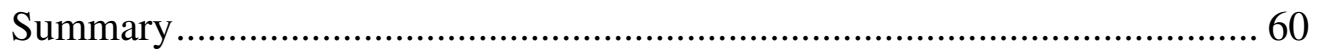

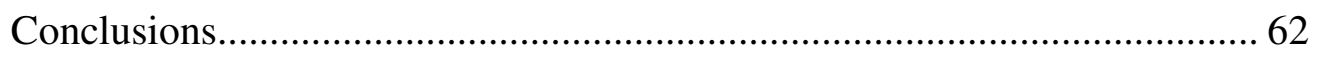

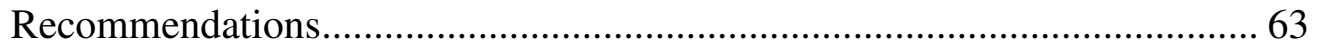

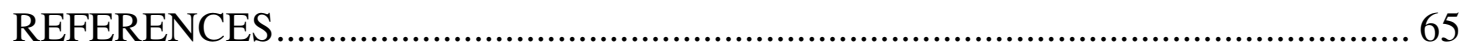

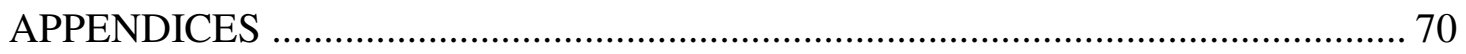

A. Interview Discussion Guide................................................................ 70

B. Description of Planned Procedures ........................................................ 73

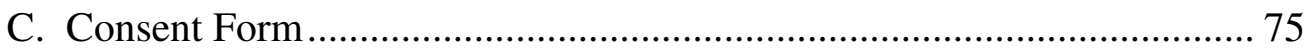




\section{LIST OF TABLES}

Title

Page

1. Reported Number of Operational Methane Digesters in the United States by Farm Type.

2. Reported Operational Methane Digesters by Digester Type, Year Operational and System End Use(s) on California Dairies.................................... 8

3. Reported Non-Operational Methane Digesters by Digester Type, Year Operational and System End Use(s) on California Dairies............................... 9

4. Summary of Background Data for Operating and Non Operating Methane Digesters

5. Summary of Installation Costs for Operating and Non Operating Methane Digesters.

6. Summary of Background Data Collected from Participants Considering Adoption.

7. Summation of Category Coding of Responses Used in the Analysis data for of the Adoption of Methane Digestions on California Dairies 


\section{LIST OF FIGURES}

Figure Page

1. Coding Categories for Hypothesis Testing............................... 31 


\section{CHAPTER I}

\section{INTRODUCTION}

California is the leading dairy producing state in the United States, with 1,496 dairies and approximately 1.7 million cows producing over 40 million pounds of milk annually and comprising more than one-fifth of total production in the United States (California Department of Food and Agriculture, 2013). However, historical shifting trends in California's dairy industry have resulted in major changes in its overall industry structure; the number of California's dairies continues to decrease, while individual herd size has increased (Capper, Cady, \& Bauman, 2009). Further, there is growing attention paid to environmental impacts of manure management systems, with stricter environmental regulations imposed by regulatory agencies (California Department of Food and Agriculture, 2013).

The California dairy industry's shift toward fewer dairies is associated with the economic difficulties faced by small family owned dairies as they try to compete in the market place. As a result, many family run dairies in California have shutdown, liquidated their businesses, relocated, or merged to improve efficiencies and/or economies of scale (California Department of Food and Agriculture, 2013). The closure of small dairies in California has lead to the merger or acquisition of assets resulting in the emergence of large scale dairies. In 2000, the average number of cows per dairy 
operation was 696 cows; however, by 2012 that number had grown to 1,186 cows per operation $^{1}$ (California Department of Food and Agriculture, 2013).

Dairy farming in general produces a substantial amount of animal waste. The average lactating dairy $\operatorname{cow}^{2}$ produces a reported average of 80lbs of wet manure a day, of which, $80 \%$ is realistically recoverable by existing waste management systems (Van Dyne, 1994). The increase in herd size has concurrently increased the amount of waste produced at individual California dairy sites, especially those counties located in the southern San Joaquin Valley; Fresno, Tulare, Kings, and Kern County, respectively (California Department of Food and Agriculture, 2010). Increasing individual herd size and regional concentration of dairy livestock operations have led to increased amounts of potential pollutants from decomposing livestock manure (Capper, Cady, \& Bauman, 2009). The large amounts of manure generated, in many cases is applied to crops, must sit in transit from animal housing to the field or be stored for later use, causing environmental impacts including: odor emissions, methane emissions, and potential water quality issues. State and local regulations coupled with limited amount of land base available for most dairies have made appropriate and efficient waste management an important issue facing the dairy industry (Hurley \& Summers, 2013).

Anaerobic methane digesters, a biogas production and collection technology, has been around for decades. Methane digesters have the potential to provide the dairy industry with an apparent solution to the issue of dairy waste management by providing a

\footnotetext{
${ }^{1}$ According to the California Department of Food and Agriculture, these figures represent the number of milk cows in production and do not include calves, heifers, bulls kept on site, dry cows, or cows which have just given birth.

${ }^{2}$ According to the Environmental Protection Agency, lactating cows differ considerably in the amount of manure they produce, depending on the breed. Holsteins produce $40 \%$ more manure than Jerseys.
} 
ready supply of renewable energy while potentially mitigating some other impacts of manure management on the environment. Methane digesters can potentially capture a renewable energy in the form of methane gas, electricity and heat (Hurley \& Summers, 2013). They can also create valuable process byproducts, such as fiber solids for animal bedding material or mulch (USEPA, 2013). Studies have been done on the economic salinity of methane digesters in recent years; however it's unclear whether they are yet economically feasible (Hurley \& Summers, 2013).

Several factors can affect the production of renewable energy and potential pollution prevention of greenhouse gases of anaerobic methane digesters, and depends largely on the manure handling practices use by dairy producers. Size of the operation, approach to waste management, regional location and governing regulations coupled with electricity and carbon reduction prices could influence cost-effectiveness of these systems (Key \& Sneeringer, 2011).

An estimated 1,000 dairies in California would financially benefit from the installation of a methane digester (Lazarus, 2008). However, despite recent studies ${ }^{3}$ reporting possible positive forecasted economic returns for sale of biogas and biogas byproducts captured by methane digesters, that could reduce production costs and comply with regulatory agency goals, especially in California, producers remain unconvinced; adoption of methane digesters has been slow (Moser, Mattocks, \& Moore, 2000; Hurley,

\footnotetext{
${ }^{3}$ Economic feasibility studies often only analyze fixed costs and/or apply the highest price per carbon reduction credit ton or $\mathrm{kWh}$, using the best case scenario for government subsidies and/or grants, and exclude costs associated with permitting, construction, installation, maintenance, management or changing economics.
} 
Ahern, \& Williams, 2007; Key \& Sneeringer, 2011; Meyer \& Powers, 2011; USEPA, 2014c).

To determine why this technology has not been widely adopted in California, information was elicited from producers who have firsthand experience with methane digester technology. A case study method was used to analyze the data, similar to those used in the past (Morse, Guthrie, \& Mutters, 1996; Lusk, 1998; Moser, Mattocks, \& Moore, 2000; Kramer, 2004), to address the efficacy of methane digesters at the farm level.

Qualitative case study research has been shown to complement quantitative data collected for traditional farm management analysis; often uncovering new information that would not have come to light by traditional methods alone (Howard \& MacMillan, 1991). The questions posed in this study utilize qualitative methods, descriptive in nature, and have been used to form the basis for the development of more general theories (Babbie, 2007).

\section{$\underline{\text { Problem Statement }}$}

Much research has been done to attest to the viability and economic sustainability of on-site dairy anaerobic digester technology, and its solution to the issues raised by the changing dynamic of California's dairy industry in general; however, the question remains as to why this technology has not been more widely adopted by California dairymen. The goal of this project is to address the possible barriers to entry, specifically the lack of training and technical support as reasons for low adoption rates of this technology in California. 


\section{Hypothesis}

Lack of training and technical support of the various mechanical aspects and technical issues associated with methane digesters have directly contributed to the low adoption of this technology at the farm level.

\section{Objectives}

1) To identify dairy producers reasons why methane digester technology has not been widely adopted on California dairies.

2) To assess the level of real world successes or failures of this technology on California dairies.

3) To assess dairy farmer concerns and problems with current implementation and up-keep of methane digester technology on site.

4) To identify any issues directly or indirectly associated with methane digester technology specific to California.

\section{$\underline{\text { Justification }}$}

California is the largest dairy producing State in the Nation; subsequently a vast amount of manure is produced as a result. Dairy producers, if they have the available land, often store much of the nutrient rich manure produced by their cows to be applied to production feed crops throughout the year, or they have to contend with the cost of shipping wet manure to another off-site location. In either case, the resulting emission of biogas into the air and potential water quality issues provide an environmental and economic incentive to adoption of methane digesters in California (Hurley \& Summers, 2013). 
Biogas emitted by decomposing manure is mainly comprised of methane $\left(\mathrm{CH}_{4}\right)$, and carbon dioxide $\left(\mathrm{CO}_{2}\right)$. Recent studies have reported to methane emissions be approximately 25 times more polluting (heat trapping) than carbon dioxide $\left(\mathrm{CO}_{2}\right)$ as a greenhouse gas, thus increasing the importance of capturing this gas at the farm level instead of releasing it (Yvon-Durocher et al., 2014) .

California dairies vary according to dairy herd size, location, available resources, production facilities and operational costs. However, despite such differences, they must all comply with existing and changing waste management programs in their regions, for example, in May 2007, the Central Valley Regional Water Quality Board adopted a general Waste Discharge Requirements General Order for Existing Milk Cow Dairies (the General Order ${ }^{4}$ ) requiring commercial dairy's in the Central Valley to fully implement their Waste Management Plan by 2011 and Nutrient management plan by 2012 (Central Valley Region Water Quatlity Control Board, 2010). The cost of compliance with the General Order is significant with one study estimating annual compliance costs of the representative groundwater monitoring program to range from $\$ 8,006$ to $\$ 47,440$ with an average cost of $\$ 19,136$ per dairy (Cady \& Francesconi, 2010). New, modified or centralized methane digesters are covered under the General

\footnotetext{
${ }^{4}$ The Central Valley Water Board first adopted the Waste Discharge Requirements General Order for Existing Milk Cow Dairies (the General Order) Order No. R5-2007-0035 on May 3, 2007. The Waste Discharge Regulatory Program for Dairy Manure Digester and Co-Digester Facilities was adopted December 10, 2010. The Waste Discharge Regulatory Program for Centralized Dairy Manure Anaerobic Digesters or Centralized Dairy Manure Co-digester Facilities was adopted by the Central Valley Water Board on 10 June 2011.
} 
Order and the time associated with the permitting processing time streamlined by $75 \%$ (Central Valley Region Water Quatlity Control Board, 2010), thereby providing an environmental and economic incentive to adoption of methane digesters in California.

Economic incentives may not mitigate all private and social costs associated with the manure waste in methane digester systems. Despite reported forecasted positive economic returns from the sale of electricity and carbon emissions reductions (or offsets), and the offsetting or stabilizing of on farm production costs, adoption of this technology at the farm level has been scant (Key \& Sneeringer, 2011; Morse, Guthrie, \& Mutters, 1996).

Table 1. Reported Number of Operational Methane Digesters in the United States by Farm Type.

\begin{tabular}{lc}
\hline Farm Type & Number of Digesters \\
\hline Beef & 4 \\
Dairy & 193 \\
Mixed & 8 \\
Poultry & 5 \\
Swine & 29 \\
Total & 239 \\
\hline
\end{tabular}

Source: (USEPA, 2014b)

The first reported operational methane digester reported by the United States Environmental Protection Agency (USEPA) in the United States, was installed at MasonDixon farms in Gettysburg Pennsylvania in 1979. In 2014, the total number of all farm based methane digesters listed as operational in the United States by the EPA was 239 (See Table 1).

The first methane digester in California was installed in Durham at Langerwerf dairy located in Butte County, in 1982 (see Table 2). Of the 193 dairy methane digesters reported operational in the United States, only 26 of these digester systems have been 
installed in California, and of those 17 are currently operational (see Table 2; USEPA, 2014b).

Table 2. Reported Operational Methane Digesters by Digester Type, Year Operational and System End Use(s) on California Dairies.

\begin{tabular}{|c|c|c|c|c|}
\hline Dairy Name & County & Digester Type & $\begin{array}{l}\text { Year } \\
\text { Operational }\end{array}$ & $\begin{array}{l}\text { Biogas End } \\
\text { Use(s) }\end{array}$ \\
\hline $\begin{array}{l}\text { ABEC Bidart-Old } \\
\text { River LLC }\end{array}$ & Bakersfield & Complete Mix & 2013 & Electricity \\
\hline $\begin{array}{l}\text { ABEC Bidart- } \\
\text { StocNO4ale LLC }\end{array}$ & Bakersfield & Covered Lagoon & 2013 & Electricity \\
\hline $\begin{array}{l}\text { ABEC New Hope } \\
\text { LLC }\end{array}$ & Galt & Covered Lagoon & 2013 & Electricity \\
\hline Antonio Brasil Dairy & Merced & Complete Mix & 2013 & Electricity \\
\hline $\begin{array}{l}\text { Bob Giacomini } \\
\text { Dairy }^{\mathrm{a}}\end{array}$ & Marin & Covered Lagoon & 2009 & Cogeneration \\
\hline Bullfrog Dairy & Imperial & Covered Lagoon & 2008 & Electricity \\
\hline CAL-Denier Dairy & Sacramento & Covered Lagoon & 2008 & Electricity \\
\hline $\begin{array}{l}\text { Castelanelli Bros. } \\
\text { Dairy }\end{array}$ & $\begin{array}{l}\text { San } \\
\text { Joaquin }\end{array}$ & Covered Lagoon & 2004 & Electricity \\
\hline Cottonwood Dairy ${ }^{\mathrm{b}}$ & Merced & Covered Lagoon & 2004 & Cogeneration \\
\hline Fiscalini Farms & Stanislaus & Complete Mix & 2008 & Cogeneration \\
\hline Hilarides Dairy & Tulare & Covered Lagoon & 2004 & Electricity \\
\hline Langerwerf Dairy & Butte & $\begin{array}{l}\text { Horizontal Plug } \\
\text { Flow }\end{array}$ & 1982 & Cogeneration \\
\hline Meadowbrook Dairy & $\begin{array}{l}\text { San } \\
\text { Bernardino }\end{array}$ & $\begin{array}{l}\text { Horizontal Plug } \\
\text { Flow }\end{array}$ & 2004 & Electricity \\
\hline New Hope Dairy & Galt & Complete Mix & 2011 & Electricity \\
\hline Straus Family Dairy & Marin & Covered Lagoon & 2004 & Cogeneration \\
\hline $\begin{array}{l}\text { Tollenaar Holsteins } \\
\text { Dairy }\end{array}$ & Sacramento & Complete Mix & 2008 & Electricity \\
\hline $\begin{array}{l}\text { Van Warmerdam } \\
\text { Dairy }\end{array}$ & Galt & Complete Mix & 2011 & Electricity \\
\hline
\end{tabular}

Source: (USEPA, 2014b)

${ }^{a}$ The Bob Giacomini Dairy is also known as Point Reyes Cheese Company.

${ }^{\mathrm{b}}$ Cottonwood Dairy is part of a five dairy conglomerate owned by Joseph Gallo Farms. Joseph Farms Cheese Company operates the digester at Cottonwood Dairy.

The remaining seven digesters reported as having shutdown or non-operational are reported in Table 3 (Table 3; USEPA, 2014b). 
In recent years dairy producers in California have been investigating the feasibility of implementing and operating methane digesters that allow them to convert methane into a renewable energy source. Engineers have developed system designs suitable to California, relating to component configuration, dairy waste collection and removal, along with other factors influencing efficiency. However, dairy producers

Table 3. Reported Non-Operational Methane Digesters by Digester Type, Year Operational and System End Use(s) on California Dairies.

\begin{tabular}{|c|c|c|c|c|}
\hline Dairy Name & County & Digester Type & $\begin{array}{l}\text { Year } \\
\text { Operational }\end{array}$ & $\begin{array}{l}\text { Biogas End } \\
\text { Use(s) }\end{array}$ \\
\hline Cal Poly Dairy & $\begin{array}{l}\text { San Luis } \\
\text { Obispo }\end{array}$ & Covered Lagoon & 1998 & Electricity \\
\hline Eden-Vale Dairy & Kings & $\begin{array}{l}\text { Horizontal Plug } \\
\text { Flow }\end{array}$ & 2006 & Cogeneration \\
\hline $\begin{array}{l}\text { Inland Empire Utilities } \\
\text { Agency - Regional } \\
\text { Plant } 1\end{array}$ & $\begin{array}{l}\text { San } \\
\text { Bernardino }\end{array}$ & Complete Mix & 2003 & Electricity \\
\hline $\begin{array}{l}\text { Inland Empire Utilities } \\
\text { Agency - Regional } \\
\text { Plant } 5\end{array}$ & $\begin{array}{l}\text { San } \\
\text { Bernardino }\end{array}$ & $\begin{array}{l}\text { Horizontal Plug } \\
\text { Flow }\end{array}$ & 2001 & Electricity \\
\hline Koetsier Dairy & Tulare & $\begin{array}{l}\text { Horizontal Plug } \\
\text { Flow }\end{array}$ & 2005 & Electricity \\
\hline Lourenco Dairy & Tulare & Covered Lagoon & 2006 & $\begin{array}{l}\text { Flared Time } \\
\text { Gas }\end{array}$ \\
\hline St. Anthony Farm & Sonoma & Covered Lagoon & 2007 & Cogeneration \\
\hline Van Ommering Dairy & San Diego & $\begin{array}{l}\text { Horizontal Plug } \\
\text { Flow }\end{array}$ & 2004 & Electricity \\
\hline Vintage Dairy & Fresno & Covered Lagoon & 2008 & Pipeline Gas \\
\hline
\end{tabular}

Source: (USEPA, 2014b)

must be able to compensate for the time it takes to implement a digester and the associated time and cost of installing and maintaining the system and for the performance of digester to be cost-effective for them to invest in a technology that will allow them to generate electricity from the methane produced. Additional research, besides environmental and economic factors into the qualitative issues associated with 
implementing and operating a methane digester by the dairy producer is needed to better understand the all aspects of implementing and operating a methane digester. 


\section{CHAPTER II}

\section{LITERATURE REVIEW}

\section{Methane Digestion Technology}

Methane digesters, also known as bio-digesters, enable biogas recovery systems via anaerobic digestion — a biological process of decay by which bacteria (methanogens) breakdown organic waste material in the absence of oxygen. The California Energy Commission (CEC) defines anaerobic digestion as a biological gasification process that produces a renewable energy source from organic wastes such as livestock manure and food processing waste, which is composed of $60 \%$ methane $\left(\mathrm{CH}_{4}\right)$ and $40 \%$ carbon dioxide $\left(\mathrm{CO}_{2}\right)$ and $0.2-0.4 \%$ hydrogen sulfide $\left(\mathrm{H}_{2} \mathrm{~S}\right)$ gasses are collectively known as biogas. However, methane digesters can provide numerous benefits to dairy producers and the environment besides a renewable energy source through the gasification process of anaerobic digestion (Wright, 2001; Borjesson, 2006).

This technology first gained notice as an energy source in the 1970's, due to the high cost of petroleum. At the time there existed many design obstacles and economic issues which prevented widespread adoption (Van Dyne, 1994). In recent years, anaerobic digestion systems utilizing primarily livestock manure for on-farm or off-farm use, have again received attention because of their ability to produce renewable energy, as energy prices soared.

Reasons for low adoption rates identified in past studies included: prohibitive financial cost associated with the construction and installation prevented many farms from adopting (Key \& Sneeringer, 2011). Factors of design incompatibility, failed 
revenue streams, prohibitive operating and maintenance costs, and scant support services available also decreased adoption (Morse, Guthrie, \& Mutters, 1996; Wright, 2001). Other disincentives include labor costs, delays, and costs associated with operation and maintenance of these digester systems (Morse, Guthrie, \& Mutters, 1996). One study found $80 \%$ of the cost of maintenance was associated with post-digester components comprised of engine repair, maintenance, and dealing with utilities, not daily operation and management of the system (Moser, Mattocks, \& Moore, 2000).

\section{$\underline{\text { System Designs }}$}

There are approximately 1.8 million lactating cows in California and dairy cow manure contains approximately 12-13\% solids as excreted (Wright, 2001), which generates annual quantities of 7 million tons of volatile solids (VS). Methane digesters systems of various designs have been reported to produce a substantial amount of energy in the form of biogas or in the form of energy and heat from all this animal waste (Summers \& Williams, 2013). Depending upon the state and region they are located, methane digestion systems can utilize a wide range of configurations including; variations in scale and configuration, a range of temperature, $\mathrm{pH}$, organic loading rates and methane recovery potential (Borjesson, 2006), and the resulting differences in composition and distribution of manure have been reported to have some affect on levels of bioconversion (Wright, 2001). However, the quality of the biogas or methane produced, regardless of system design or facility was reported to be consistent, meaning their heating value was the same (Summers and Williams, 2013). The three digester systems that are reported to exist in California are ambient-temperature covered-lagoon, complete-mix, and horizontal plug-flow digesters (Krich, et al., 2005). 
Covered lagoons are anaerobic lagoons which are sealed and operate at ambient temperatures, meaning they are not heated. These systems utilize a flexible fitted cover for biogas recovery and are fitted with a pipe to the combustion device. Covered lagoons are reported to be the most popular digester design in California (USEPA, 2014b). Covered lagoons are comprised of diluted wastes from dairy parlors and housing sheds wash using a flush dairy manure system. Lagoon style digesters have the potential to reduce manure solids by 26\% (Summers \& Williams 2013).

Complete-mix digesters are designed as enclosed aboveground tanks that are usually heated and insulated. Complete-mix systems utilize hydraulic or mechanical agitators or some sort of gas mixing system to mix the excreted manure. This agitation is used to keep the material in consistent slurry with $2 \%$ to $10 \%$ solids. Complete mix digesters are reported to work best when the excreted manure is diluted with water (USEPA 2014d). Material leaving the digester digestate will contain a fraction of the just added manure (Wright, 2001).

Plug flow digesters are reportedly used only at dairy operations that collect manure by scraping Plug-flow anaerobic digester systems and are found in greater numbers in cooler climates other than California. A plug flow digester is designed with a long, narrow concrete chamber or tank with a rigid or flexible cover, and is built partially or completely below ground to limit the demand for supplemental heat (USEPA, 2014d). Plug-flow digesters consist of unmixed, heated rectangular tanks that function by horizontally displacing old material with new material. Plug-flow digesters are used to digest thicker wastes of $11 \%$ to $13 \%$ solids, and are best suited for manure handling systems that do not contain less than $10 \%$ solids which is what flushed manure or dry lots 
to lagoon system do, thus rendering them unsuitable for most California dairies (Moser, Mattocks, \& Moore, 2000). Manure is collected using either a flush system or scrap system and is added to one end of an insulated holding container, which flows into the main digester. The manure added forces out an equal amount of effluent from the other end of the digester as digested effluent (Wright, 2001).

Anaerobic covered lagoons have seasonal variation in gas production due to the variation in ambient temperature and are best suited for dairies in the West (Moser, Mattocks, \& Moore, 2000). Gas production from complete-mix and plug-flow digesters are impacted less by ambient temperature variation since they are usually heated. Once the digester captures the biogas, the gas is usually transferred to another point to be processed prior to its intended end point. This generally means the gas has been to be scrubbed to remove impurities, to be used to power a combustion engine or generator unit, or for injection in to a natural gas pipeline. The remaining effluent inside the digester is made up of salts, nutrients and the leftover organic matter that was initially present in the animal feed and can dried for further use (Meyer \& Powers, 2011).

\section{$\underline{\text { Design Trends }}$}

Many of the problems associated with methane digesters in the 1970's were due to a lack of understanding of the biological system used. The result was that the digester was treated more as a physical process that could be started and stopped by turning on or shutting off the waste flow instead of a complex bio-mechanical system (Wright, 2001). According to the USEPA (2014) methane digester project database, from the 1980's to the 1990's approximately thirty methane digesters were installed on various types of 
agricultural operations ${ }^{5}$ across the U.S., though these systems had a better performance rate than previous systems, due to a more simplified design (Wright, 2001), nearly half of these systems failed or were shutdown according to the EPA methane digester database.

Prior to 2000, only fourteen digesters were reported operational according to the EPA, however, from 2000 to 2011, a reported 176 methane digesters, most of these at the farm level, were installed across the U.S. In California, prior to 2000 only two methane digesters were in existence, one operating and one shutdown.

In 2011 , nearly $50 \%$ of anaerobic digesters installed in the United States were complete mix, with mixed plug flow digesters comprising another $40 \%$. These systems continue to be the dominant technology designs in relation to all operating anaerobic digester systems in the U.S. The remaining $10 \%$ of new digester systems were covered lagoons. In contrast, from 2000 to 2011 , California reported $50 \%$ of the digestion systems in existence were covered lagoon systems, $30 \%$ were complete mix, and $20 \%$ were horizontal plug flow systems (see Table 1 and 2) (USEPA, 2014b).

Although the majority of systems use only livestock manure and are farm-owned and operated, other approaches are emerging. In Europe, a study done in Sweden showed large potential for anaerobic digestion and methane digestion in proper waste ratios at large centralized wastewater treatment plants. These facilities are reported to show great potential for co-digestion of livestock manure and clean organic urban and industrial wastes (Davidsson, et al., 2007).

In the United States, centralized systems are an area of growing consideration where dairy, swine, or poultry farms are too small to support a cost-effective on-farm

\footnotetext{
${ }^{5}$ Farm types listed by the EPA database include dairy, swine, duck, chicken and beef operations.
} 
facility (Hurley, Ahern, \& Williams, 2007; Lusk, 1998). Approximately $30 \%$ of project operators reported co-digestion systems running "high-strength" organic wastes, such as cheese whey in those dairies in close proximity to a cheese making facility, and urban waste (Lehtomaki, 2007; USEPA, 2014c). Regardless of design, an anaerobic digester requires an oxygen free, closed environment; therefore the digester design is based on the system of animal waste collection used (Meyer \& Powers, 2011).

\section{Dairy Waste Collection and Removal}

Engineers have designed a number of manure waste handling and collection systems. These systems vary greatly, and each method or system has its own set of benefits and drawbacks. However, the purpose is the same, moving manure away from the cattle into some collection end point. The three primary manure collection methods used on California dairies are scraper systems (integrated mechanical or tractor scrapers), flush water system, and vacuum systems. Nearly two-thirds of California dairies use a flush water management system and the remaining use a scrape system. Flush dairies ${ }^{6}$ are the best candidates for biogas production compared to other methods where manure is scraped and stored and will decomposes aerobically, inhibiting the development of the bacteria that create biogas (Krich et al., 2005).

\section{Factors Influencing Efficiency}

The three digester systems in use on California dairies are ambient-temperature covered-lagoon, complete-mix, and horizontal plug-flow digesters (Krich, et al., 2005;

\footnotetext{
${ }^{6}$ California dairies have to consider the cost of water use (flush system) versus the cost of labor (scrape or vacuum system), and often a flush waste removal systems is the most cost effective.
} 
USEPA, 2014b). Of the 26 California dairy digesters, half are covered lagoon systems (USEPA, 2014b). The three temperature ranges that methanogens produce methane are psychrophilic, mesophilic and thermophilic (Rico, 2006). Bioconversion of waste (liquid manure) to methane gas produced depends on several factors including temperature, and pH level.

A covered lagoon system operates (psychrophilic conditions) at 68 degrees or less, and thus significantly effects the rate of anaerobic digestion and amount of methane gas produced (Wright, 2001). Most complete-mix and plug-flow digester systems operate at either mesophilic or thermophilic temperatures. The optimal ranges for anaerobic digestion are between 125 to $135^{\circ} \mathrm{F}$ (thermophilic conditions) and between 95 to $105^{\circ} \mathrm{F}$ (mesophilic conditions) (Rico, 2006).

Mesophilic temperature systems are reported to be the prevailing temperature design in relation to all operating digester systems in the U.S. (Nishio, 2007; USEPA, 2014c), though drainage of solid and semisolid material through the digester becomes difficult in mesophilic concentrations with greater than $10 \%$ solids (Nishio, 2007).

Under thermophilic conditions, digester systems can generate gas in a shorter amount of time than anaerobic digestion under mesophilic conditions. A trade off however, is that more energy is required to maintain thermophilic conditions within the reactor. The additional heat could be captured from excess heat from the generator engine or another outside source (Krich, et al., 2005).

In all three of the temperature ranges, methanogens breakdown the solids in manure, refered to as total solids (TS), into volatile solids (VS), which typically comprise $70 \%$ of TS, while the remaining $30 \%$ is inorganaic matter. VS are then further divided 
into biodegradable and non-biodegradable VS, with the biodegradable portion of VS (approximatly half) converted into carbon monoxide and methane gas (Wright, 2001).

The bioconversion rate of any methane digestion systems may differ by a factor of $2-4 \%$ for $\mathrm{CH}_{4}$ and by $11 \%$ for $\mathrm{SO}_{2}$ depending on the properties of the raw material digested. The raw organic properties of various wastes effect production of methane digestion systems especially for manure (Borjesson, 2006). The production of $\mathrm{CH}_{4}$ can take 18 to 24 days in an anaerobic digestion system containing dairy manure to produce a $90 \%$ of the potential biogas yield (Rico, 2006).

\section{$\underline{\text { U.S. Policies in Support of Methane Digesters }}$}

Policy makers, government agencies and environmental groups have created a great deal of support in the form of programs and incentives for biogas recovery technology at the state and federal level (USEPA, 2014d). There are a number of factors that have driven policy makers to pass legislation in favor of methane digesters and other renewable energies (Duncan, 2004). Over the last decade, several policies have been implemented for methane digesters at the farm level, which provide financial incentives for dairy farmers to use digester technology to reduce methane emissions and environmental impacts. These programs include educational and technical support, grants and loans for capital items, feasibility studies, environmental policy and research (USEPA, 2014d).

There have been approximately 22 current, expired or pending federal programs that have provided direct or indirect support for biofuels (Yacobucci, 2012). One example is the AgSTAR program, a collaborative venture of federal agencies including 
the USDA, USEPA and USDOE which provides educational materials and online project evaluation tools and funding options ${ }^{7}$ (USEPA, 2014d).

Over the last decade, support in favor of renewable biofuels has been evident in key pieces of legislation that have made methane digester technology appealing, most notably the 2008 Farm Bill—The Food, Conservation, and Energy Act of 2008, which established several biofuel incentives, including several new grant and loan programs, in support of anaerobic digesters at the farm level (Yacobucci, 2012), and effectively reinvigorated the push for adoption of methane digesters at the farm level. The renewable Fuel Standard (RFS) established by The Energy Policy Act of $2005^{8}$, which in 2009 was expanded upon to specifically mandate the use of advanced biofuels (like those produced by methane digesters) on livestock operations (Yacobucci, 2012).

More recently, in 2010, the USEPA and the USDA earmarked \$3.9 million in funds ${ }^{9}$ to encourage adoption of methane digesters on conventional livestock operations (USEPA, 2014c). Political support from the dairy industry itself has been evident with its goal to voluntarily reduce greenhouse gas emissions by $25 \%$ by 2020 coupled with a

\footnotetext{
${ }^{7}$ These funding options can be found through the Database of State Incentives for Renewables and Efficiency (DSIRE) (United States Department of Energy, 2014).

${ }^{8}$ The (RFS) was established in 2005 by The Energy Policy Act of 2005 and expanded on by the Energy Independence and Security Act of 2007, and expanded on again in 2009 and 2011. The EPA ruled on the (RFS) in 2007 and again with the expanded program (RFS2) in 2010 (Yacobucci, 2012).

${ }^{9}$ Finding for this was provided by the UCA2A's Natural Resource Conservation Service's (NRCS) Environmental Quality Incentive Program (EQUIP), as well as several programs from the Rural Energy for America Program (REAP), the Bioenergy Program for Advanced Biofuels, and the Bio-refinery Assistance Program (Yacobucci, 2012).
} 
partnership with the USDA in $2009^{10}$, and renewed again in May 2013 (USDA, USEPA, and USDOE, 2014).

In March of 2014, the current administration released The Climate Action Plan (CAP) formulated by a consortium consisting of USDA, USEPA, USDOE (2014), and dairy industry representatives. In August 2014, President Obama released the Biogas Opportunities Roadmap ${ }^{11}$, outlining voluntary measures that dairy farmers and producers can implement to increase the adoption of methane digesters.

Funding and support for these machines at the State level depends on location and other factors. Ultimately, the funding of projects at the farm level comes from a combination of sources including: the farmers themselves, private investors, grant and loan programs and regional utility companies. In California, the regional Sacramento Municipal Utilities Department (SMUD) for example, in accordance with greenhouse gas reduction goals of the California Municipal Utilities Association, received millions in funding from the DOE and the CEC, to help fund the construction of methane digesters in their district ${ }^{12}$ (Sacramento Municipal Utilities District, 2014). A great deal of support at the state and federal levels was evident in policies then applied to methane digester technology as prices of energy rose.

\footnotetext{
${ }^{10}$ The Dairy Industry set forth the voluntary goal of reducing methane emission by $25 \%$ by 2020 in 2008 , prior to its partnership with the UCA2A in 2009. The partnership was renewed in 2014.

${ }^{11}$ The Dairy Industry and UCA2A's renewed partnership in 2014 resulted in the creation of the voluntary Biogas Opportunities Roadmap in August 2014 (U.S. Department of Agriculture, U.S. Environmental Protection Agency, U.S. Department of Energy, 2014)

${ }^{12}$ Funds for digesters constructed through SMUD came from the Department of Energy's Community Renewable Energy Deployment (CRED) grant program, which in turn came from the American Recovery and Reinvestment Act of 2009 (Sacramento Municipal Utilities District, 2014).
} 


\section{Opportunities for Methane Digesters}

Potential revenue sources for methane digesters on California dairies include the collection and sale of biogas, heat and electricity generation. However, each potential end use has its pros and cons. Federal and State support for renewable energies has helped create a market for the sale of biogas and facilitated the sale of electricity from anaerobic digesters by prompting contractual arrangements between the regional utilities and dairies with methane digesters or those considering implementing one. Alternatively, biogas collected from a methane digester can be piped back into the gas pipeline, however, it requires a secondary treatment as it contains between $0.2-0.4 \%$ hydrogen sulfide $\left(\mathrm{H}_{2} \mathrm{~S}\right)$, which converts to sulfuric acid, and is highly corrosive to engine generators (Wright, 2001).

Most methane digestion systems installed on dairies in California are designed to generate electricity as their final energy output (USEPA, 2014b). The generation of electricity from biogas for profit is determined by the contractual arrangement of the regional utility company. Electrical energy contracts for dairies with methane digesters in California are usually negotiated in one of three ways: a buy-all-sell-all, a net metering agreement or a surplus sale arrangement (California Public Utilities Commission, 2014). A buy-all-sell-all contract allows the utility company to sell a dairy all electricity requirements, and buys all the generator output. A net metering contract allow for electricity produced to be offset on a monthly or yearly basis against consumption, and the surplus energy produced to then be purchased by the utility company and shortages purchased by the dairy. A surplus sale contract allows the electricity produced by a 
digester to be sold at avoided $\operatorname{cost}^{13}$ and excess consumption at the retail rate (USEPA, 2014c). However, this means that electrical prices are locked in at the time of the negotiated contract, essentially forecasting future electricity prices, which has been shown to be variable. Interconnection to the grid can also be variable and associated costs and logistics can be challenging (Gloy \& Dressler, 2010).

Carbon credits, or emission reduction credits, are derived from the biogas collection device or gas treatment system before either flare (burn-off) or other end use (USEPA, 2014c). A gas treatment system is needed to remove high concentrations of hydrogen sulfide in dairy manure in order to prevent corrosion of the combustion device (Wright, 2001). According to the EPA, carbon credits are based on "baseline emissions", that is how much methane a given dairy produced prior to the installation of a methane digester. Currently, dairy producers in California have the option to sell carbon credits in regional or voluntary markets when a given amount of carbon emissions allowed for a dairy is not used, they can be traded for a profit (USEPA, 2014c). One study showed sales of carbon credits to be profitable with herds in excess of 600 head (Key \& Sneeringer, 2011). However, voluntary market prices tend to be low and variable, and often require a third-party offset verification company in order to sell the emission reductions leaving most farmers to consider the process too costly to sell carbon credits (Gloy \& Dressler, 2010).

\footnotetext{
${ }^{13}$ Avoided Cost is defined as the marginal cost for a public utilities company to produce one more unit of power. In California, a utility company's avoided costs are determined by the California Public Utilities Commission (CPUC) in public hearings, and are designed to simulate a market price for energy (California Public Utilities Commission, 2014).
} 
The Dennis Haubenschild Dairy near Princeton, MN, was one of the pioneers in trading carbon credits from captured methane. These carbon credits were sold on the Chicago Climate Exchange, at the time, the only market for greenhouse emissions credits. The dairy was the first to run a methane digester in Minnesota, and the first digester in the world to run a hydrogen fuel cell off of biogas (Bilek, 2006).

\section{$\underline{\text { Case Study Research }}$}

There are a number of qualitative methods that can be used to collect primary data to then be used in a structured study with quantifiable results. Qualitative data collected from surveys is the most common method used for exploratory purposes (Kumar, Aaker \& Day, 2001; Babbie, 2007). Exploratory research obtained through surveys can be used for defining problems in more detail, for generating new ideas or production concepts, to finding solutions to problems, and for suggesting interesting questions or concepts to be examined in subsequent research. Feelings, thoughts, insights, behaviors and intentions are examples of data that can be obtained through qualitative survey data collection (Kumar, Aaker \& Day, 2001).

Qualitative interview methods and field research techniques allow for exploratory and conceptual in-depth discussions between the researcher and participant rather than quantitative analysis of financial and/or survey data (Howard \& MacMillan, 1991). A main strength of this approach is open ended, in-depth interviews often yield observations not easily reduced to numbers. Researches may recognize nuances of attitude and behavior that might escape research using other methods (Babbie, 2007). This setting allows for the study of those attitudes and behaviors best understood within their natural surroundings as opposed to an artificial setting and can lead the researcher to 
develop a deeper and fuller understanding of meaningful comments, suggestions and insights (Babbie, 2007).

A case study approach and multiple case study approach use qualitative field research interview techniques to examine an instances or separate instances. The individual case study inquire copes with the technically distinctive situation in which several variables of interest are present than data points. Similarly, the researcher relies on multiple cases of evidence with multiple sources of data and increasing variables needing to converge in a cohesive manner in order to guide data collection and metaanalysis. Both the individual and multiple case study designs require researchers entering the field with full knowledge of existing theories that aim to uncover contradictions that require modification of those theories (Babbie, 2007). Previous case study research which addressed the efficacy of anaerobic digesters on dairy farms (Morse, Guthrie, \& Mutters, 1996; Kramer, 2004; Lazarus, 2008) had used qualitative interview methods to obtain primary data points from producers who have firsthand experience with methane digester technology, and thus provided the logical starting point for this study.

Multiple case study planning begins with the creation of a discussion guide or agenda. The purpose of the research is set into questions to address the research objectives. The discussion guide is comprised of a base set of topics selected ahead of time to be discussed in-depth, rather than specific formalized questions during each interview. The interviewer proceeds with a logical flow from general questions to key questions or specific issues (Kumar, Aaker \& Day, 2001; Babbie, 2007).

When recruiting participants it is appropriate to incorporate similarities and contrasts within a given group. The participants may all be dairymen for example, but 
they may differ by geographical region, dairy size, by levels of education and waste collection method. Scheduling individual interviews to accommodate the participant is also important, and should take place within a relatively limited area and time frame (Babbie, 2007).

Critical to the quality of commentary collected from each participant is the level of ease the participant has with the researcher, established by rapport. The researcher should give an introduction about the purpose of the study, the general approach to the topic, what can be expected from the interview and the expected time frame of the interview. In addition, the researcher should ensure that the information obtained during discussion will be kept confidential (Babbie, 2007).

In addition the researcher should encourage discussion of attitudes and perceptions of issues related to the topic as well as feelings, anxieties, and frustrations without bias or pressure. The researcher should dress appropriately, be respectful and show great interest in the topic by listening carefully to commentary. The researcher should be flexible and have the ability to control conversations in a smooth flow by redirecting a participants' wandering commentary back to key topics and know when a topic is becoming uncomfortable or exhausted (Kumar, Aaker \& Day, 2001). Field research guidelines for conducting case study interviews include: preparing for the field, identifying appropriate topics for field research discussion, tools for analyzing social situations, the various roles of the observer, and how to correctly managing the relation to subjects by establishing a rapport (Babbie, 2007).

When writing the report the analyst would give background and purpose of the study and organize the data in an accessible and relative manner, which means organizing 
responses into categorical tables that would become the worksheets for writing the report.

The researcher would also provide transcripts for each of the participating dairies

(Babbie, 2007). 


\section{CHAPTER III}

\section{METHODOLOGY}

\section{$\underline{\text { Data }}$}

Eighteen dairies were identified through the USEPA's AgSTAR website, through discussions with dairymen, and through advising Cal Poly faculty contacts as possible candidates for this study. The sample criterion was based on available data. Budgetary restrictions of the study limited the available sample to coastal Northern and Central California dairy producers and any non-response bias of producers in those two regions. The regional sample population $(n=18)$, criteria included; having had experience with methane digesters or interest in implementing this technology. Those eighteen dairies meeting the aforementioned criteria were contacted by telephone to determine their willingness to participate in the case study, and to schedule a time of their choosing to conduct an in-depth interview at their facility, or agreed upon location. The age, gender and ethnicity of the subjects were predominantly male, Caucasians, and approximately $30-65$ years of age.

Of the dairies contacted, twelve responded and agreed to participate in this study. The twelve subjects who participated in the study fell into one of three categories; dairy producers who have installed a methane digester is currently operational $\left(\mathrm{n}_{1}=4\right)$, dairy producers who have installed a methane digester in the past that was currently nonoperational $\left(\mathrm{n}_{2}=4\right)$, and dairy producers who are considering implementing a digester on their farm $\left(n_{3}=4\right)$. 
Personal interviews were conducted in person, and one on one, with dairy owners or employee representatives. The interviews were spread out over a 12 month period, from August 2013 through August 2014. A copy of the questions included in the discussion guide (see Appendix A) was sent by email to each participant a week ahead of time, for them to review, prior to the scheduled interview. Each interview held was taped with the use of a portable audio recorder, and transcripts were made available to each survey participant. Consent for the interview and participation in the study was obtained at the beginning of each interview with the provided consent form (see Appendix C). The names of the participating parties and the dairies were then given an option of confidentiality, so as to elicit fuller commentary or response. Participants were told the purpose of the study and were given the option to omit or not answer any question asked by the interviewer.

The discussion guide used during the interviews is included in Appendix A. The guide consisted of 24 open-ended questions, designed to encourage the participants to be as descriptive as possible in their responses. Ice-breaker and background questions were asked to lead into the main topic of methane digesters. Introductory questions about the history of each dairy, number of family members working there and highest level of education were discussed. Further background questions relating to overall agricultural production and operation, crops farmed, number of employees, relationship with processors and any consultants they contracted with, were then discussed. Participants were then questioned about their decision to install a digester on their dairy, company chosen (or considered) to design and install the digester, troubleshooting services offered, 
and approximate cost to install the digester, any financial incentives, and how long they had considered this technology.

Participants were then questioned about their knowledge and experience with methane digesters or possible installation. Exploratory questions eliciting reasoning for installing this technology include; how the digester fit (or would fit) into their daily operation, the time spent operating and maintaining it, who operates and maintains the digesters (or would) when problems arise and any training they received were discussed. The interviewer then asked questions relating to the performance evaluation and expectation of the methane digester. Participants were asked to explain reasons why expectations were or were not met, how the performance of this technology differed from their initial expectations (or what the initial performance expectations were), in hindsight what they would have done differently (or their assessments for the technologic future), and reasons why they would or would not reinvest in this technology again (or what help form their opinion of the adoption of this technology). Finally, to wrap up, participants were provided the opportunity to discuss any question asked further, provide any an additional comments or suggestions or "take away advice" on their experiences or thoughts that had not been brought up.

The qualitative or textual data analyzed in this study utilized qualitative data processing methods to objectively categorize all textual data by using coding units (Babbie, 2007), with the aim of discovering patterns among the responses to questions pertaining to experience with methane digesters. The twelve interviews were analyzed for such content, specific insights, and consistency. The responses derived from each interview were then transcribed into text. Coding labels were assigned to primary 
themes, once all the data was transcribed, organized, analyzed several times over to insure confidence in data assessment (see Figure 1). 
Figure 1. Coding Categories for Hypothesis Testing

\begin{tabular}{|c|c|c|c|}
\hline Category & Definition & Examples & $\begin{array}{c}\text { Coding } \\
\text { Rules }\end{array}$ \\
\hline $\begin{array}{l}\mathrm{C} 1 \text { : high competence } \\
\text { or confidence or } \\
\text { positive } \\
\text { experience/opinion }\end{array}$ & $\begin{array}{l}\text { High subjective } \\
\text { conviction to have } \\
\text { successfully maintained a } \\
\text { digester, to be confident in } \\
\text { the demands or } \\
\text { expectations of the } \\
\text { digester and to have had a } \\
\text { positive, hopeful feeling } \\
\text { in about this technology. }\end{array}$ & $\begin{array}{l}\text { "Of course there } \\
\text { had been some } \\
\text { little problems, but } \\
\text { we solved them all, } \\
\text { either I was to fix } \\
\text { it or was able to } \\
\text { get help to fix the } \\
\text { problem". }\end{array}$ & $\begin{array}{c}\text { All three } \\
\text { aspects of } \\
\text { the } \\
\text { definition } \\
\text { have to point } \\
\text { to "high" } \\
\text { self } \\
\text { confidence } \\
\text { no aspect } \\
\text { only } \\
\text { "middle". } \\
\text { Otherwise } \\
\text { C2: middle } \\
\text { self } \\
\text { confidence }\end{array}$ \\
\hline Category & Definition & Examples & $\begin{array}{l}\text { Coding } \\
\text { Rules }\end{array}$ \\
\hline $\begin{array}{c}\text { C2: middle } \\
\text { competence or } \\
\text { confidence or mid- } \\
\text { level } \\
\text { experience/fluctuating } \\
\text { opinion }\end{array}$ & $\begin{array}{l}\text { Only partly or fluctuating } \\
\text { conviction to have } \\
\text { successfully coped with } \\
\text { the digester demands. } \\
\text { Ambivalent experiences } \\
\text { or expectations. They are } \\
\text { of two minds or } \\
\text { undecided about this } \\
\text { technology. }\end{array}$ & $\begin{array}{l}\text { "Quite often I } \\
\text { found it hard to } \\
\text { maneuver through } \\
\text { the initial problems } \\
\text { with the digester, } \\
\text { but finally I made } \\
\text { it work." Or "In } \\
\text { time everything } \\
\text { got better, but I } \\
\text { couldn't you if it } \\
\text { was worth it." }\end{array}$ & $\begin{array}{l}\text { If not all } \\
\text { aspects of } \\
\text { definition } \\
\text { point to } \\
\text { "High" or } \\
\text { "low" }\end{array}$ \\
\hline Category & Definition & Examples & $\begin{array}{c}\text { Coding } \\
\text { Rules }\end{array}$ \\
\hline $\begin{array}{c}\text { K3: low } \\
\text { understanding or } \\
\text { competence or have a } \\
\text { negative } \\
\text { experience/opinion }\end{array}$ & $\begin{array}{l}\text { Conviction to have badly } \\
\text { coped with the digesters } \\
\text { operational/maintenance } \\
\text { demands, or to have a } \\
\text { negative, pessimistic } \\
\text { feeling or experience with } \\
\text { the digester, to be } \\
\text { pessimistic, negative } \\
\text { about this technology. }\end{array}$ & $\begin{array}{c}\text { "I thought it } \\
\text { wouldn't be that } \\
\text { hard to manage, } \\
\text { but it was over my } \\
\text { head." }\end{array}$ & $\begin{array}{c}\text { All three } \\
\text { aspects of } \\
\text { definition } \\
\text { point to low } \\
\text { confidence, } \\
\text { or negative } \\
\text { experience, } \\
\text { no } \\
\text { fluctuations } \\
\text { recognizable }\end{array}$ \\
\hline
\end{tabular}

Source: (Mayring, 2000) 
A coding label triage sorted responses into three categories: high competence or confidence or positive experience/opinion (C1), mid-level competence or confidence or fluctuating opinion (C2), and low level competence or confidence or having a negative opinion of methane digester technology (C3). The coding categories were defined and coding rules were formed. An example of a $\mathrm{C} 1$ category response read "Of course there had been a few initial problems with the digester, but we solved them all, either I was able to fix it or had someone help fix the problem". An example of $\mathrm{C} 2$ responses were "Quite often I found it hard to maneuver through the problems with the digester, but finally figured something out." Or "In time everything sort of got better, but I couldn't tell you if it was worth it" and a C3 response would read "I thought it wouldn't be that hard to manage, but it was over my head" and "I just don't see a future for this technology".

The responses to the primary questions that addressed the use or planned implementation of methane digesters were analyzed and reemerging themes or topics were identified in the textual data. Representative sample responses were selected to illustrate typical view points. Primary topics or issues were grouped into heading categories: troubleshooting, training, operation and maintenance, funding, time commitments and constraints, motivational factors and expectations and performances of the methane digester.

Key questions and their responses were systematically sorted into rule guided qualitative text within a framework of the three previously defined categories (Mayring, 2000), to test the hypothesis (see Figure 1). Primary concepts or themes were then identified and sorted into categories that satisfied the four objectives. Data collected 
from the responses underwent cross-case analysis, using an open coding and "axial $\operatorname{coding}^{14}$ " and meta-analysis identifying core concepts or primary issues that best address the objectives and test the hypothesis of the study. (Babbie, 2007).

\section{$\underline{\text { Assumptions and Limitations }}$}

The manner in which a qualitative interview question is asked can greatly affect the measure of openness in answers given by participants. The asking of questions relating to the management and operation of any business can be perceived as invasive and can elicit responses such as; "why do you want to know?" and "what are you going to do with this information?". Careful consideration was taken to make sure any question asked was neutral in context, with no positive or negative bias. However, often the interviewer must make careful behavioral decisions during the interview to negate any suspicions held by the participant and to establish a rapport with the interviewee in order to obtain more candid insights and opinions during (Babbie, 2007). Slight adjustments on behalf of the researcher were made over the course of the interviews; however the order of questions asked was maintained to elicit a logical smooth flow from one topic to the next (Kumar, Aaker \& Day, 2001).

Given the size and differences in the regions-no two dairies are alike. There were too many variables to include in the scope of this study, and combined with the reality of so few examples of methane digesters on dairy farms, gives good reason to

\footnotetext{
${ }^{14}$ Axial coding is defined as the reanalysis of the results of open coding in the Grounded Theory Method, aimed at identifying the important, general concepts (Babbie, 2007).
} 
interpret any data cautiously. The responses given are those of the participating dairies, and my not represent those of the dairy industry as a whole. 


\section{CHAPTER IV}

\section{RESULTS}

Primary topics or issues that addressed the adoption of methane digester at the farm level were identified in the response data. These issues consisted of recurring themes that consistently appeared throughout the interview response analysis. Primary issues and corresponding groups include: troubleshooting, training, operation and maintenance, funding, time commitments and constraints, motivational factors, expectations, and performances of methane digesters. The primary topics or issues addressed dairy farmers concerns and problems with installation and up-keep of methane digester technology at the farm level. To better illustrate these primary issues, respondents were separated into two groups; those who had firsthand experience with methane digester technology and those who considered adopting. Participants that had firsthand knowledge along with a summary of their background information are represented in Table 5. Generalizations, commonalities and differences were then discussed to further illustrate the extremes, median and deviations within the two groups.

The four dairies with operational digesters were labeled as operational $1(\mathrm{O} 1)$, operational $2(\mathrm{O} 2)$, operational $3(\mathrm{O} 3)$ and operational $4(\mathrm{O} 4)$. The four dairies with nonoperating digesters were labeled non-operating (NO1), non-operating (NO2), nonoperating (NO3) and non-operating (NO4). The four remaining dairies who had considered adopting this technology were labeled as considering adoption 1 (CA1), considering adoption 2 (CA2), considering adoption 3 (CA3) and considering adoption 4 (CA4). 


\begin{tabular}{|c|c|c|c|c|c|c|c|c|}
\hline & \multicolumn{8}{|c|}{ Dairy Producer } \\
\hline & O1 & $\mathrm{O} 2$ & $\mathrm{O} 3$ & $\mathrm{O} 4$ & NO1 & $\mathrm{NO} 2$ & NO3 & $\mathrm{NO} 4$ \\
\hline Years & $\begin{array}{l}2009 \text { to } \\
\text { Present }\end{array}$ & $\begin{array}{l}2008 \text { to } \\
\text { Present }\end{array}$ & $\begin{array}{l}2004 \text { to } \\
\text { Present }\end{array}$ & $\begin{array}{l}2011 \text { to } \\
\text { Present }\end{array}$ & $\begin{array}{l}1998 \text { to } \\
2005\end{array}$ & $\begin{array}{l}2007 \text { to } \\
2008\end{array}$ & $\begin{array}{l}2008 \text { to } \\
2012\end{array}$ & $\begin{array}{l}1985 \text { tc } \\
1986, \\
2002 \text { tc } \\
2009, \\
\text { Fall of } \\
2014\end{array}$ \\
\hline $\begin{array}{l}\text { Herd } \\
\text { Size }\end{array}$ & $<300$ & 2600 & 5000 & 1500 & $<300$ & $<300$ & 2800 & 2000 \\
\hline $\begin{array}{l}\text { Baseline } \\
\text { System }\end{array}$ & Lagoon & $\begin{array}{l}\text { Complete } \\
\text { Mix }\end{array}$ & Lagoon & $\begin{array}{l}\text { Complete } \\
\text { Mix }\end{array}$ & Lagoon & Lagoon & Lagoon & Lagoor \\
\hline $\begin{array}{l}\text { Digester } \\
\text { Operator }\end{array}$ & Employee & $3^{\text {rd }}$ Party & Employee & $3^{\text {rd }}$ Party & $\begin{array}{l}\text { Resident } \\
\text { designer } \\
\text { and P.E. }\end{array}$ & Employee & Employee & $\begin{array}{l}3^{\text {rd }} \\
\text { Party }\end{array}$ \\
\hline $\begin{array}{l}\text { Cheese } \\
\text { Plant/ } \\
\text { Creamery }\end{array}$ & Yes & Yes & Yes & & & Yes & & \\
\hline
\end{tabular}

\section{$\underline{\text { Troubleshooting }}$}

When asked about troubleshooting issues nearly all the participants reported facing issues that required technical support from a knowledgeable source.

Troubleshooting services were reported to mean telephone consultation with a technician and online support. Most of the participants reported having limited initial support during the installation process. However, once installation was complete, most participants reported no support services were made available by the supplier or installation company. Although, when pressed further, most participants reported they were able to reach out to contacts in that industry for some friendly assistance and troubleshooting advice.

$\mathrm{O} 1, \mathrm{O} 2$ were the only two producers that reported having an initial telephone and online troubleshooting support package when the methane digester was installed. 
However, their experiences were very different. O1 dairy attributed much of their success with their digester to a three year mandatory service agreement with the company that installed the digester, Martin Machinery, which was required by PG\&E. O1 dairy operated and managed the methane digester themselves but when problems arouse, they were able to contact the installation service technician for troubleshooting by telephone and online remote access. The participant mentioned that online monitoring allowed the producer to identify any problems that would arise during off hours. In addition, the installation service technician would then utilize the online remote access to diagnose the problem and make recommend adjustments to resolve the issue. The ability to diagnose an issue quickly without having to schedule a service representative to visit and/or have the producer (or an employee) onsite was seen as the primary reason by the producer for the success of their methane digestion system. O1 went on to say that in the first year of operation, the online service saved their generator engine from having to be replaced more than once.

In contrast, $\mathrm{O} 2$ (prior to contracting with a third party management company) was able to utilize limited troubleshooting technical support through an online screen sharing remote access (team viewer program) with the manufacturing company for the first year, as part of the methane digester's installation package. However, $\mathrm{O} 2$ reported that because the company was located in Germany, the time difference made scheduling an online interface difficult and therefore was not helpful in diagnosing issues quickly.

When asked about particular troubleshooting services offered, three of the eight participants-- O2, O4 and NO4-- reported that they had decided to contract with a third party management company rather than deal with the digester themselves. The third 
party management company, for all three cases, had a service representative come out to perform routine engine/generator maintenance every 10 days or two weeks. O4 further mentioned that should any issues arise the third party operative would send out a text alert informing the owners about the issue.

The two exceptions with regard to troubleshooting and or available maintenance services were NO1 and NO3. NO1 was a pilot project by a resident professional designer Professor Douglas Williams, at Cal Poly State University, where the methane digester was located, who at the time provided troubleshooting and maintenance with the aid of student workers. NO3 was a pilot project of the bio-energy firm, Energy Solutions LLC (now closed after filing for bankruptcy in 2012), and as such, could not comment on whether or not they would have offered support services to future clients.

\section{$\underline{\text { Training }}$}

When asked about the amount of training involved in the operation and maintenance of the digester, most participants reported that no formal training was provided by the supplier beyond the initial startup. One participant that had contracted with a third party operative, (O4) stated that they received around 20 hours of instruction on how to run a weekly test on the bacterial health of the digester, as part of the contractual agreement.

As previously mentioned, NO1 and NO3 were again the exception with regard to needing any training, as they were both experimental pilot projects by industry professionals; NO1 was part of the curriculum to instruct University students in biotechnology and engineering, and NO3 was the pilot project of a bio-technology startup firm. However, both participants reported giving a significant amount of 
instruction/training to those employees or students operating the methane digester. Coincidently, NO3 reported that there was one primary employee who received a significant amount of training from the company, a graduate of Cal Poly State University (previously mentioned) and former student of resident designer Williams, who was employed by the bio-tech firm, and was instrumental in the installation of NO2 and once installed chiefly in charge of monitoring the digester daily and performed any maintenance required.

NO4 was a unique case, although they had reported receiving no training at all with their first digester, saying "there were components to it that they had no idea what they were or what they did". However NO4 did receive some initial training with their second methane digester on how to check the $\mathrm{pH}$, gas contents and perform some analysis on a regular basis. NO4 went on to mention that they thought the digester was very time consuming and that it was another thing he had to constantly think about, watch and maintain.

\section{Operation and Maintenance Issues}

When asked about operating and maintaining the methane digester, all participants with methane digesters, reported that repairs were a common issue of concern, and 50\% reported having issues with sourcing replacement parts. Most participants reported having to make numerous technical repairs that required some measure of skill. Most attributed the reason for these occurrences to either basic maintenance issues resulting from normal wear and tear and or poor design.

The issue of sourcing parts was mentioned as a significant concern among producers. Many participants remarked that parts and components needed for repairs 
were not easily sourced, meaning they were not available at local hardware stores. NO2 dairy for example, upon closure in 2008 , sold off many of the digester components and parts as replacement parts to Straus Dairy in Sonoma County (which declined to participate in this study), who operated a methane digester.

Interestingly, all participants, including those with a third party operative, commented that it was a "learning experience." Despite the number of differences and levels or competency in working with this technology, every participant in the study expressed the sentiment that methane digester systems were not instantaneously successful, and required more effort than originally anticipated.

Six of the eight participants had reported numerous technical issues associated with operating their methane digesters. These six participants went on to say that those issues resulted in poor output by the digester and were attributed to design flaws. Four of the six participants, who reported having experienced several technical issues, stated that design flaws had directly affected their decision to continue to run their digester.

NO4 dairy stated that they had experienced numerous similar technical and design issues with the first and second start up, and stated a lack of troubleshooting support, available parts, daily maintenance, emissions regulations by the Air Quality Control Board (with regard to the engine), and overall design (they had used a vacuum manure collection method which resulted in a dirt plug) were the main reasons why the first two startups failed.

The three dairies contracted with a third party management company reported overall very satisfied with the arrangement. They felt their time could be used more wisely tending to their herds and running their dairy, and having little direct 
responsibility for the digester was reported as a most beneficial aspect. It should be noted that in each of the three cases, technical modifications and upgrades were made that allowed for co-digestion of garden waste and food waste what were additionally fed into the digester.

Two of those producers, $\mathrm{O} 2$ and NO4, who had contracted with a third party, had initially maintained their digesters themselves, but after years of dealing with numerous maintenance and repairs issues, limited troubleshooting support, and decreased digester output, they decided to contract with a third party management company. NO4 dairy was the only participant with a non-operating methane digester that was planning to restart the system in Fall 2014, and said the third startup would not have been considered without the aid of a third party management company.

O4 was the only participant who had never planned to maintain the digester themselves; from the onset they planned to have a third party company manage the system. From the dairy startup planned on installing a methane digester system primarily as a waste management system. The ability of the methane digester system to create renewable energy in the form of natural gas was what made it feasible to contract with a third party management company.

\section{Funding the Project}

The reported costs for the methane digesters varied from approximately $\$ 1$ million to $\$ 4.5$ million among the respondents. The reason for this cost variation was not directly addressed in this study. However, a summary of approximate costs associated with the digester and installation along with any grant funding that was utilized is reported in Table 5. 
Table 5. Summary of Installation Costs for Operating and Non Operating Methane Digesters.

\begin{tabular}{|c|c|c|c|c|c|c|c|c|}
\hline & \multicolumn{8}{|c|}{ Dairy Producer } \\
\hline & $\mathrm{O} 1$ & $\mathrm{O} 2$ & $\mathrm{O} 3$ & $\mathrm{O} 4$ & NO1 & $\mathrm{NO} 2$ & NO3 & NO4 \\
\hline $\begin{array}{l}\text { Associated } \\
\text { Costs }\end{array}$ & $\begin{array}{l}\text { Cost to } \\
\text { the } \\
\text { producer } \\
\$ 700,000\end{array}$ & $\begin{array}{l}\text { Total project } \\
\text { cost } \$ 4.5 \\
\text { million. } \\
\text { Cost to } \\
\text { producer } \\
\$ 2.5 \text { million. }\end{array}$ & $\begin{array}{l}\text { Total } \\
\text { cost } \\
\$ 3.2 \\
\text { million. }\end{array}$ & $\begin{array}{l}\text { Total } \\
\text { cost } \$ 3 \\
\text { million. }\end{array}$ & $\begin{array}{l}\text { Initial } \\
\text { support } \\
\text { and } \\
\text { partial } \\
\text { funding } \\
\text { from the } \\
\text { Univ. }\end{array}$ & $\begin{array}{l}\$ 650,000- \\
\$ 700,000 \\
\text { initially; } \\
\text { further } \\
\text { costs } \\
\text { overlap } \\
\text { with new } \\
\text { creamery }\end{array}$ & $\begin{array}{l}\text { MD was } \\
\text { funded } \\
\text { by } \\
\text { private } \\
\text { capital; } \\
\text { refused } \\
\text { to } \\
\text { comment } \\
\text { further } \\
\text { on costs }\end{array}$ & $\begin{array}{l}\$ 1 \\
\text { million } \\
\text { for } 1^{\text {st }} \\
\text { startup; } \\
\$ 300,000 \\
\text { for } 2^{\text {nd }} \\
\text { startup; } \\
\$ 3-4 \\
\text { million } \\
\text { for } 3^{\text {rd }} \\
\text { startup }\end{array}$ \\
\hline Grants & $\begin{array}{l}\text { Grants } \\
\text { provided } \\
2 / 3 \text { of } \\
\text { total cost. }\end{array}$ & $\begin{array}{l}50 \% \text { of } \\
\text { construction } \\
\text { and } \\
\text { installation. }\end{array}$ & $\begin{array}{l}50 \% \text { of } \\
\text { the } \\
\text { total } \\
\text { cost }\end{array}$ & $\begin{array}{l}\text { Grants } \\
\text { provided } \\
2 / 3 \text { of } \\
\text { total } \\
\text { cost. }\end{array}$ & $\begin{array}{l}\text { Grant } \\
\text { funds } \\
\text { obtained }\end{array}$ & $\begin{array}{l}\text { No grant } \\
\text { funds } \\
\text { obtained }\end{array}$ & $\begin{array}{l}\text { No grant } \\
\text { funds } \\
\text { obtained }\end{array}$ & $\begin{array}{l}\text { Grant } \\
\text { funds } \\
\text { obtained } \\
\text { in } 2^{\text {nd }} \\
\text { startup }\end{array}$ \\
\hline
\end{tabular}

When asked about initial costs, the numbers varied from all four dairies with operational digesters, $\mathrm{O} 1, \mathrm{O} 2, \mathrm{O} 3$ and $\mathrm{O} 4$; however, all four explained that they received grants from the state and federal government that covered at least $50 \%$ of the initial cost of the digester. $\mathrm{O} 1$ and $\mathrm{O} 4$ stated that 2/3rds of the cost of the digester was covered by grants. The remaining cost was covered by the dairy. Grant funding was a factor that most participants reported was essential to the decision of installing a methane digester. Six of the eight participants with digesters, O1, O2, O3, O4, NO1 and $\mathrm{NO} 4$ reported they would not have implemented this technology without substantial grant funding.

Two of four dairies with non-operating digesters, NO1 and NO4, had received grants that covered some portion of the digester. NO2 dairy stated that their personnel did not recall receiving any grant funding to build the digester, and that those sorts of incentives were not available or known to them at the time (2006-2007). NO3 dairy 
declined to talk about the cost of the digester, but did state that they did not receive any grants funds, that it was all private capital.

\section{$\underline{\text { Unforeseen Costs }}$}

Seven of the eight respondents reported the total cost of installing a digester exceeded initial estimates. The reasons for the increase in cost varied, although most attributed these extra costs to site-specific configuration or design issues, extended installation timelines and additional labor costs. Examples of reported site specific installation costs included; topography of the dairy (having the digester located below the overflow ponds), high ground water, poor stabilizing soil, the relining of a pond, the addition of a second pond, and several system reconfigurations, all of which cumulatively added several months of additional labor and dirt excavation work. The one exception was NO1, which stated that they could not recall (due to the 16 year laps in time) if the digester project cost more than initially anticipated.

Although the circumstances were different, similar configuration and design related installation costs were reported by seven of the eight participants. A few examples of design issues reported were inadequate piping configurations (too few moisture trap-filters were used to reduce the amount of hot moist air captured from a lagoon methane digester systems in route to the generator/engine) and the wear and tear of daily startups and shutdowns of the generator or diesel engine). These issues resulted in poor output by the digester and subsequent shutdowns.

Additional labor costs incurred during installation were reported by more than half of the participants. Poor communication between different industries and fields that often converge when installing digester systems was reported by one participant as a 
reason digester projects fail or incur unforeseen installation costs. One participant mentioned one reason digester products fail or incur unforeseen installation costs are the communication between the digester engineers, project managers and the dairyman or herdsman is mired in disagreement, meaning they are not effective at communicating both ways, resulting in project delays and additional expense. Most notable was the experience $\mathrm{O} 2$ reported; their methane digester was expected to cost around $\$ 2$ million but by the end of the extended site preparation and construction timeline, the total cost was $\$ 4.5$ million dollars.

Half of the participants reported installing a digester to complement the redirection of their overall production with the addition of a cheese making facility or creamery and/or switching to organic practices. An extreme example of this was NO2, which reportedly had decided to redirect their entire conventional production operation to an organic operation, build a creamery and launch a new product line in partnership with the milk processor Clover Stornetta LLC, (Petaluma). The participant reported that the initial installation of the methane digestion system incurred many unforeseen costs including; additional ground excavation costs, site configuration issues, and additional labor costs to help maintain the digester. The participant further reported mounting costs to operate and maintain the digester and creamery along with a poor economy were reported to have led to the closure of the dairy in 2008 .

In an extreme case, NO4 reported poor planning and additional labor costs were believed to be the reasons why their first two methane digesters failed. The participant reported that a manure vacuum collection method was used in conjunction with a lagoon digester design, which was said to be incongruous and ultimately problematic. The 
producer stated that a significant amount of dirt was collected (along with the manure and waste water) and transferred to their lagoon methane digester, which resulted in poor system output. NO4 reportedly did not switch over their waste collection system from a manure vacuum to a scrape system (as suggested by the manufacturer) believing it would be too costly at that time. The participant reported that that decision ultimately resulted in the same problematic plugging in both their first and second methane digesters. The producer went on to say that unforeseen cost associated with parts and labor to maintain the generator and the hiring of additional part-time labor to conduct repairs (help clean out the dirt that plugged up the system) proved too costly and also contributed to the failure of the first and second digester. NO4 further mentioned that, additional system upgrades and the assistance of grant funding to mitigate those costs made the second startup more successful, despite continuing to use a manure vacuum system. However, NO4 reportedly had to walk away from those grants because the methane digester did not meet emission standards of the Central Valley Regional Water Quality Control Board. NO4 concluded that a scrape system was to be part of the third methane digesters system upgrades, and would be installed by the third party operative (NO4's third system would be run exclusively by a third party operative).

Five of the eight participants reported having to hire additional labor to manage their digester and further stated that the additional expense was not originally factored into the total cost of owning and operating their methane digester system. The increase in labor cost reported by $\mathrm{O} 1, \mathrm{O} 2, \mathrm{O} 3, \mathrm{NO} 2$ and $\mathrm{NO} 4$, coupled with the time and cost to maintain the required energy output from their methane digester over time (often 
attributed to design or normal wear and tear) created unforeseen costs that undermined the economic feasibility of those of those systems.

Of those participants who reported having to hire a person to manage their methane digester, most said that hiring someone with a mechanical background rather than a dairy background was of greater priority (given the technical nature of the system). A best case scenario can be made for O1, who was able to hire the digester operator at NO2 (once NO2 was closed and liquidated) to manage the installation and daily maintenance of their digester fulltime. The methane digester operator at NO2 had been involved with the installation, and possessed both technical experience and a dairy management background.

The operator of $\mathrm{O} 1$ (formally NO2) was said to be pleased with how the digester system had performed. However, the producer was not as optimistic in his assessment of their methane digester, stating that it was hard to put an exact number to how much the digester was saving the dairy (electricity costs, propane costs, and sourcing and storage of hot water required) but said he was satisfied none the less. The producer went on to mention that the mandatory service contract required by PG\&E (mentioned previously) was an additional unforeseen costs that was not originally factored into the decision to own and operate a methane digester; however this unforeseen cost was considered fortunate in that the service provided had reportedly contributed to the success of their digester.

Participants $\mathrm{O} 2, \mathrm{O} 3$ and NO4 shared a similar negative viewpoint with regard to incurred unforeseen costs and the hiring of additional labor to manage the digester. All three experienced significant increase in costs associated with initial construction, site 
preparation and the increased labor costs with hiring part-time or full-time help to manage their methane digesters. The personnel hired by those three participants were reported to have a background in mechanics and little or no experience in the dairy industry.

Ultimately, all three participants referred to their methane digester as being a "bog project" meaning the initial investment and continuous cost of operating and maintaining the system along with the decrease in output by the methane digester was considered to be an ever increasing loss. An extreme case was reported by $\mathrm{O} 2$, which in addition to having to hire a full-time employee to operate the digester after the first year, also reported having to acquire parts from overseas (their supplier was a German company), having to arrange shipping for replacement parts, and contend with customs delays, which amounted to substantial unforeseen costs. The producer went on to say that the system became a burden because it cost more to operate and maintain than the system was contributing to their operation. The producer further explained that the expenditure incurred with the initial investment of $\mathrm{O} 2$, together with monthly loan payments and labor costs and increased hours spent to manage the system, could not be recovered, and by its second year in operation, hiring a third party operator was the only viable option for recovering at least some of their loss.

\section{$\underline{\text { Time Constraints and Commitments }}$}

When asked about time constraints and commitments relating to any aspect of how operating a digester fit into the everyday production schedule of the participants, the amount of time varied. Half of the participants reported spending anywhere from 20-45 minutes a day on average checking on the digester, and every two to three weeks 
spending more time on basic engine maintenance. The other half reportedly spent two to three hours a day checking and monitoring their methane digester. Two participants, $\mathrm{O} 2$ and NO4 went on to say that over a period of years, that amount of time increased to four to five hours/day spent maintaining their digester. The participants reported the reason for this was a decrease digester output over time, eventually leading to contract with a third party operator. Similarly, $\mathrm{O} 3$ reported that it was necessary to hire a fulltime employee to run the four engines needed to handle the seven acre lagoon digester's gas production.

When asked how much time was taken to consider installing this technology, all eight participants with digesters reported that it took a year or more to fully research the topic and come to a decision. O1 reported that they had considered the idea of a methane digester for awhile, ever since the installation of a methane digester system at nearby dairy, Straus Family Creamery Dairy (Marshall), but not until they had visited several dairies with digesters, conducted an energy audit, and determined that a methane digester would best suit their needs, did they implement one.

Similarly, O2 dairy stated they visited several dairies with methane digesters in California and the Midwest and considered many different designs, including those used in Europe. Eventually, they reportedly decided on a German company because of it its simplistic design (an above ground configuration), overall efficiency, and fewer moving parts. In contrast, $\mathrm{O} 4$ dairy stated they knew they wanted to incorporate the use of a digester eight years before (when they acquired the dairy). O4 reported the main reason for installing a methane digestion system was that they felt it would best integrate their waste management and soil nutrient management programs. 
One participant, an environmental law attorney with family ties to the dairy industry and CEO of the bio-tech firm Energy Solutions LLC, when asked how long he had considered implementing this technology, replied that it took years to learn about how digesters work, eight months to negotiate a contract with the utilities, another nine months to figure out how to build one, and then another nine months to actually build a methane digester. More than most people wanted to know.

\section{$\underline{\text { Motivation for Adoption }}$}

Seven of the eight participants reported the aim of incorporating environmentally friendly and renewable energy practices was a primary motivation for adoption of this technology, meaning those respondents reported a desire to both introduce green energy practices and reduce their on-site energy costs as the primary motivators. Limited facilities and land was also reported by every participant in the group to be another important reason to implement this technology since a digester would reduce the amount of land needed to store manure waste for later for application to pasture and/or crops or for transport to an off-site location.

Although, almost all participants stated that a desire to produce renewable energy was the primary reason for implementing this technology. O4 was an exception to this because the motivation to install their digester system first to improve their nutrient and waste management system and second to generate renewable energy. The lack of available land was reported to be problematic, because they had no place to treat and store their manure waste, and that prior to installing the methane digester they had shipped wet manure to an off-site location. The producer went on explain that shipping wet manure was costly (and messy) and more importantly, posed additional nutrient 
management issues. The participant then stated that in their case, a fortunate combination of their dairy's layout characteristics; an above ground tank configuration, with a scrape waste removal system, that slopes downhill from the barns and sits alongside a natural gas line allowing easy access to the grid, was said to be the reason for their digester success.

Four participants, $\mathrm{O} 1, \mathrm{O} 2, \mathrm{O} 3$ and $\mathrm{NO} 2$, reported partial motivation to install a digester came from a desire to better address the needs of their cheese making or creamery facilities. Producers reported the additional waste produced by the cheese making or creamery facility was fed to the digester as an input instead of sold as another product, due to smaller economies of scale, and the waste water and cheese byproducts (curds and whey) from the cheese making facility and milk fats from the creamery was then converted into energy as an output. Participants reported that all the energy output from their digester was then used for either electricity, for sourcing and collecting heat for a boiler used in the cheese making plant, and for nutrient management in their pastures. The four participants went on to say that they had also utilized the separated solids left over from anaerobic digestion, for bedding for cows and/or to sell peat moss or fertilizer to local nurseries.

Two participants, NO1 and NO3, also reported entrepreneurial motivation for installing a digester. NO1 was a pilot project by a resident professional designer Doug Williams P.E., PhD, a leader in anaerobic digester research, at Cal Poly State University (previously mentioned), who stated that the University methane digester pilot project was the impetus to later found Williams Engineering Associates an engineering service company that has designed digesters throughout California. NO3 was a flagship project 
for BioEnergy Solutions (Bakersfield) in 2008 (previously mentioned). The firms CEO possessed a degree in environmental law who had over 10 years of experience negotiating contracts between utilities and dairies looking to implement digesters.

\section{Issues Related to Expectations and Performance}

When participants were asked about their initial expectations and performance of their digester, six of the eight participants reported that their initial expectations were met with regard to digester performance and energy output, but that's where the similarities ended. The two participants, $\mathrm{NO} 2$ and $\mathrm{NO} 4$ who experienced performance issues from the start, explained that as a result would operate their methane digesters intermittently, which was hard on their generator/engine causing excess wear. This problem was reportedly further exacerbated by increased load levels, from too much manure waste added at one time, when their methane digester was operating.

NO4 went on to report that they were dismayed with regard to expectations and performance of the digester during both startups. The producer stated that he anticipated being able to operate their methane digester without much trouble, however once their methane digester was installed, the producer reported that he was unable understand the components, chiefly the complexity of the gages and control levers, and further stated that he was completely in over his head following the installation of their first digester in 1985. NO4 further explained that technical and management issues with the amount of management time required to operate the methane digester, and not meeting emission regulations, coupled with their decision to use a vacuum system instead of replacing it with a scrape system (as previously mentioned), added to the overall poor performance of the first two startups. 
Two participants reported that for the first 6-12 months expectations were met, but were ultimately dissatisfied. Reported the performances of $\mathrm{O} 2$ and $\mathrm{O} 3$ diminished after the first year. The operational and maintenance costs specific to the design of $\mathrm{O} 2$ (a German company designed the digester), configured to meet Germany's emission regulation standards were different from those in California. As a result producer became disenchanted with the technology in general and handed it over to a third party to manage. Similar performance issues were reported in $\mathrm{O} 3$ with regard to diminishing energy output and increasing operational and maintenance costs over time. The operator explained that the seven acre lagoon style digester had reportedly filled with too many solids and as a result may soon be shut down permanently due to insufficient solid separation. Technical issues and maintenance costs required to keep the digester operational were considered prohibitive. These costs were reported to include a new cover, clearing out the system of dirt, and technical issues with the circulation pump. The participant went on to explain that these costs combined with the dairy's change in leadership, meaning those who originally advocated for the adoption of the digester are no longer there, has led to an overall feeling of dissatisfaction.

When given the opportunity to further explain any additional performance exceptions, six of the eight participants reportedly thought their digesters would be able to accomplish more than they did. One participant (O4) reportedly met all expectations as a waste management and nutrient management tool, but the participant further mentioned that they thought the methane digester would have delivered a more significant byproduct revenue stream. They had hoped to sell the separated solids from the digester as compost to local plant nurseries. Similarly, O1 was reported to have met 
expectations as an environmentally friendly renewable energy source, as a nutrient waste management tool and by providing usable by-products, such as bedding; however, the producer was disappointed to find the methane digester covered many, but not all of the dairy's energy needs.

NO3 was the only system which reportedly exceeded expectations with regard to digester output; however, poor communication resulted in two project expectations that were not met. The first was the problematic communication issues during the planning and installation process. The second issue was the poor communication between the dairy and the utility company. The participant explained that their project engineers did not configure the layout of the methane digester system properly, and instead positioned the overflow pipe from the digester to the lagoon in such a way as to move the manure uphill, which is counterintuitive to most dairy industry people. Similarly, the communication between the utilities was also reported to be problematic, seven different times, a lower than usual output from the digester was detected by PG\&E, and when investigated by the dairy, the digester was found to be operating effectively. The participant went on to explain that the issue was with PG\&E's faulty stop values, which had malfunctioned, and would not allow the gas to enter into the utility gas pipeline. The participant stated that PG\&E was not required to maintain their system to the same standards as the dairy.

Somewhat surprisingly five of the eight participants, O1, O4, NO1, NO3 and $\mathrm{NO} 4$, reported that they would reinvest in this technology again, while $\mathrm{O} 2, \mathrm{O} 3$ and $\mathrm{NO}$, reported that they would not reinvest in this technology and would have preferred to invest in traditional waste management systems. The participants who reported that they 
would reinvest further stated that they believed in this technology, and felt that it made the most sense for the future of the dairy industry. However, many qualified their response by further recommended that anyone looking to adopt this technology should do their homework, meaning they should visit as many digesters as possible-all over the world, study their financial requirements, make use of available grant funding, research emerging technologies, understand the geographic location and relation to certain utilities, and be familiar with the regulations in that area.

\section{$\underline{\text { Issues for Considering Adoption }}$}

We now switch gears and examine the results of the group of dairies considering methane digesters. The reported impetus for considering adoption varies, but some similarities were noted. Those participants considering adopting methane digester technology were asked to comment on the amount of time considering installing a digester, economic feasibility, expectations for operating and maintaining this technology, and any other issues. A summary of background information collected from those participants considering adoption were reported in Table 6.

When asked about the amount of time the participant spent considering and/or researching this technology, most had done little research. One producer explained that the process was time consuming and estimated that it would take two or more hours a day, for two weeks to research this technology properly, on top of all the daily production requirements. The producer then went on to explain that regardless of their decision, whether to install a digester or not, the banks were not too friendly to dairymen and that as a small dairy with less than 300 head (small by California dairy farm standards), they could not afford such a capital intensive investment. 
Table 6. Summary of Background Data Collected from Participants Considering Adoption.

\begin{tabular}{|c|c|c|c|c|}
\hline & \multicolumn{4}{|c|}{ Dairy Producer } \\
\hline & CA1 & CA2 & CA3 & CA4 \\
\hline Herd Size & 240 & 1500 & 800 & 700 \\
\hline $\begin{array}{l}\text { Intended } \\
\text { Digester } \\
\text { Operator }\end{array}$ & Owner & $\begin{array}{l}\text { Owner \& } \\
\text { Employee }\end{array}$ & Employee & Employee \\
\hline Primary & Renewable & Waste & Organics & Renewable \\
\hline $\begin{array}{l}\text { Issues/ } \\
\text { Motivation }\end{array}$ & Energy & $\begin{array}{l}\text { Management \& } \\
\text { Organics }\end{array}$ & & $\begin{array}{l}\text { Energy \& } \\
\text { Organics }\end{array}$ \\
\hline Expectations & $\begin{array}{l}\text { Feasible at } \\
<300\end{array}$ & $\begin{array}{l}\text { Economically } \\
\text { Feasible \& } \\
\text { Income } \\
\text { Generating }\end{array}$ & $\begin{array}{l}\text { Economically } \\
\text { Feasible }\end{array}$ & $\begin{array}{l}\text { Economically } \\
\text { Feasible }\end{array}$ \\
\hline
\end{tabular}

All four of the participants in this group stated that they were interested in the future of this technology, but found cost to be the most prohibitive barrier. One participant stated that they would expect methane digester technology to be able to pay for itself within a few years, and further stated that sustainability depended on energy rates greatly improving. Another participant mentioned that they would expect such a significant investment of capital and space (not all dairies have the space for it) should be economically feasible and income generating.

When questioned about the possibility of contracting with a third party operative, all four participants seemed open to the notion of having less responsibility and said further they would rather tend to their cows. One participant reported that the first digester he had known about was at the Grossi dairy (installed in Marin in the 1970's), and said that it was extremely time consuming, and that there was not enough time in the day to add a labor intensive technology. 
Most of the participants commented that they expected a digester to require little maintenance and minimal supervision. Two of the four participants, CA2 and CA3 commented that manure is a highly caustic and corrosive substance that quickly erodes machinery, and felt that a methane digestion system and had the potential to breakdown often. CA2 further stated that they had installed a manure separator to produce much and bedding, a component that is part of most digester designs, and was not happy with the machinery. The participant explained that the separator was always breaking down and required constant maintenance and felt a methane digestion system would be no different.

One participant reportedly received a proposal from RCM Digesters, an anaerobic digester design and manufacturing company a year ago, but was not confident that the technology would be able to meet their expectations of being able to pay for itself and then some. They then decided that it was not worth considering further. The estimated costs were approximately \$3.5-4 million, and after deducting qualifying grants would cost the dairy around $\$ 600,000$ out of pocket. The producer went on to say that they already had a separator that converts their manure into dry bedding that they were not completely satisfied with it. The producers reported to be very interested in a smarter way to handle their waste, but in regard to methane digesters felt that economically the technology didn't make sense.

One participant noted that regional differences could impact the feasibility of methane digesters. Coastal Northern California dairies, for example, were reported to be very different from those in the Central Valley, where the majority of digesters have been implemented, because of regional climate differences and/or economies of scale. Dairies 
in the Central Valley are regionally drier with little to no pasture available, herds are larger and cows are typically kept in housing sheds and on dry lots. In contrast, coastal Northern California dairies experience greater rainfall and precipitation providing pasture throughout the year, herds are smaller and cows are kept out on pasture most of the time. These separate conditions create different economies of scale between the two regions and participants believed further development of this technology would be needed to improve economic feasibility of methane digestion systems on coastal Northern California Dairies.

Most participants considered the integration of methane digester and organic practices an issue of significant importance, since coastal Northern California dairies provide most of the organic milk produced in California, when they considered adopting this technology. Three of the four participants were interested in how a digester system would fit into current organic pasture management standards. One participant commented on the fact that organic herds are required to remain out on pasture for a certain number of days, and that methane digesters seemed counterproductive to the idea of a digester, meaning there wouldn't be enough volume to make the amount of energy required to be feasible as a renewable energy source. Another participant motivated by the renewable energy aspect and possible application to organic dairy practices reported that after researching the issues decided there were other "green," but less capital intensive ways of handling manure that better fit their production needs.

All four dairies said they would not invest in this technology at this time. 


\section{Hypothesis Testing}

Participant response were analyzed, sorted and objectively categorize which allowed for the researcher to discover patterns among the responses and to identify specific insights, and response consistency. A coding label triage sorted responses into three categories that allowed the researcher to test the hypothesis and are reported in Table 7. The sorted response were placed into three categories; those participants who reported a high competence or confidence and/or positive experience/opinion (C1), those participants who reported a mid-level competence or confidence or fluctuating opinion (C2), and those with a low level competence or confidence or having a negative opinion of MD technology (C3). 
Table 7. Summation of Category Coding of Responses Used in the Analysis data for of the Adoption of Methane Digestions on California Dairies.

\begin{tabular}{|c|c|c|}
\hline Dairy & Category & Response Summary \\
\hline $\mathrm{O} 1$ & $\mathrm{C} 1$ & $\begin{array}{l}\text { Digester Operational. Reinvest as long as grants were available. Confident and } \\
\text { competent at troubleshooting and maintenance. Adoption mostly positive } \\
\text { outlook. }\end{array}$ \\
\hline $\mathrm{O} 2$ & $\mathrm{C} 3$ & $\begin{array}{l}\text { Digester Operational. } 3^{\text {rd }} \text { party contract. Would not reinvest. Not confident or } \\
\text { competent with troubleshooting and technology. Mostly middle or negative } \\
\text { outlook on adoption. }\end{array}$ \\
\hline $\mathrm{O} 3$ & $\mathrm{C} 3$ & $\begin{array}{l}\text { Digester Operational. Considering Shutdown. Would not reinvest. Not confident, } \\
\text { but competent with troubleshooting and technology. Adoption mostly negative } \\
\text { outlook. }\end{array}$ \\
\hline $\mathrm{O} 4$ & $\mathrm{C} 1$ & $\begin{array}{l}\text { Digester Operational. } 3^{\text {rd }} \text { party contract. Would reinvest. Confident at } \\
\text { troubleshooting and technology. Adoption mostly positive outlook. }\end{array}$ \\
\hline NO1 & $\mathrm{C} 2$ & $\begin{array}{l}\text { Digester Non-operational. Would tentatively reinvest. Confident and competent } \\
\text { at troubleshooting and technology. Designer is optimistic but university cautious } \\
\text { due to funding. }\end{array}$ \\
\hline $\mathrm{NO} 2$ & $\mathrm{C} 3$ & $\begin{array}{l}\text { Digester Non-operational, dairy closed. Would not reinvest. Not confident or } \\
\text { competent at troubleshooting and technology. Adoption mostly mid-level } \\
\text { outlook. }\end{array}$ \\
\hline NO3 & $\mathrm{C} 2$ & $\begin{array}{l}\text { Digester Non-operational, dairy is closed. Would reinvest. Confident and } \\
\text { competent at troubleshooting and technology. Adoption mostly positive outlook. }\end{array}$ \\
\hline $\mathrm{NO} 4$ & $\mathrm{C} 2$ & $\begin{array}{l}\text { Digester Non-operational. Restart Pending with } 3^{\text {rd }} \text { party contract. Would } \\
\text { reinvest. Confident but not competent at troubleshooting and maintenance. Very } \\
\text { negative about regulatory burdens. Adoption mostly middle level outlook. }\end{array}$ \\
\hline CA1 & $\mathrm{C} 3$ & $\begin{array}{l}\text { Considering, but would not invest. Not confident at troubleshooting and } \\
\text { maintenance. Interest in renewable energy. Adoption mid-level outlook. }\end{array}$ \\
\hline $\mathrm{CA} 2$ & $\mathrm{C} 3$ & $\begin{array}{l}\text { Considering, but would not invest. Confident and competent at troubleshooting } \\
\text { and maintenance. Interest in waste management and organics. Adoption negative } \\
\text { outlook. }\end{array}$ \\
\hline CA3 & $\mathrm{C} 3$ & $\begin{array}{l}\text { Considering, but would not invest. Not confident at troubleshooting and } \\
\text { technology. Interest in organics. Adoption negative outlook. }\end{array}$ \\
\hline CA4 & $\mathrm{C} 3$ & $\begin{array}{l}\text { Considering, but would not invest. Confident but not competent at } \\
\text { troubleshooting and technology. Interest in renewable energy and organics. } \\
\text { Adoption mid-level outlook. }\end{array}$ \\
\hline
\end{tabular}




\section{CHAPTER V}

\section{SUMMARY, CONCLUSIONS AND RECOMMENDATIONS}

\section{$\underline{\text { Summary }}$}

The objective of this study was to identify qualitative reasons why methane digester technology has not been widely adopted on California dairies, and to determine whether or not a lack of training and technical support in the operation and maintenance of methane digesters technology has resulted in low adoption rates at the farm level. Additional objectives were to assess the level of real world feasibility of this technology and to assess dairy farmers' concerns and problems with installation, operation and maintenance of these systems. The final objective was to identify any issues associated with digester technology specific to California. The most compelling results of the study showed that a lack of training and support has contributed to low success rates and thus low adoption rates at the farm level. In order for widespread adoption to be feasible, a long-term service plan or third party operative would need to be in place prior to implementation.

Similar to past studies, hefty initial costs of installing a methane digester system, combined with low negotiated energy prices and changing emissions regulations were said to be the main economic reasons for a lack of adoption in California. Further, it was observed that most opinions of widespread adoption at the farm level to be negative, regardless of whether or not a dairy would invest or reinvest in the technology. Producers understand that the price of this technology, even with grant funding, is more costly and time consuming then they are willing to take on. In addition, the decreasing 
numbers of dairies - particularly small family run dairies in the State of California leave many reluctant to take on such large capital investment in a system that would take up valuable space on a dairy and would ultimately require a decades-long commitment. Producers were clear about not wanting to take on more debt or additional projects requiring any major time commitment.

Regarding the level of real world apparent success or failure of this technology, a low level of understanding and communication with regard to ongoing time and labor costs or competence in the degree of training and support required in the installation and long-term operation and maintenance of methane digesters was observed. Producers consistently report a lack of long term technical support as an issue that affects those methane digesters in operation, and as a primary contributor to the failure of non operational systems, which has further contributed to the lack of wide spread adoption at the farm level.

In addition, it was observed that a dairy's primary motivation for implementing a methane digester was for renewable energy production at the farm level, but what they actually implemented was a 24 hour, seven day a week, entirely new waste management system with limited or no training or support services; it would be similar to adding a whole new department or product line. Dairymen want to tend their cows rather than learn and manage a potentially time intensive technical and biological system. This leads the researcher to believe that if methane digesters were projected as a whole new waste management system or field of operation, rather than focusing primarily on the renewable energy aspect, dairies would have a better understanding of what would be required to successfully incorporate a methane digester into their operation. Further, it was observed 
that participants with a third party management contract were the most content and successful with their digester systems.

Issues directly and indirectly associated with preventing methane digester technology from being widely adopted at the farm level include region specific dairy management approaches to production and changing emissions regulations. The Regional Water Quality Control Boards General Order in the Central Valley is an example of a regulation policy specific to one region of California that encourages the adoption of methane digester on conventional dairies (those with high animal density), but does not apply to coastal milk producing counties. Participants felt the two regions and their requirements to be separate, with methane digesters perceived to be counterproductive to organic dairy practices, in part because of the required amount of days on pasture. In addition, in coastal Northern California dairies, where the majority of organic milk is sourced, participants consider digesters most beneficial to dairies with multiple energy end uses, such as those with a cheese making plant or creamery.

Producers considering this technology were specifically interested in the renewable energy aspect of this technology and its possible pairing with the organic dairy market. Waste management was also thought to be another issue driving the consideration of this technology, and interest in adoption of this technology increased when the involvement of a third party management company was discussed as an option.

\section{$\underline{\text { Conclusions }}$}

The purpose of this study was to determine if a lack of training and technical support of the various mechanical and management issues associated with methane digesters had directly contributed to the lack of widespread adoption of this technology at 
the farm level. The finding of this study is that the qualitative data collected is persuasive enough to conclude that a lack of training and technical support of the various mechanical and management issues associated with methane digesters, has directly contributed to the low widespread adoption of this technology at the farm level.

\section{$\underline{\text { Recommendations }}$}

The findings of this study emphasize the overall impression of a lack of comprehensive technical and biological competence required to operate and maintain a digester over the long-run is complex and was not fully understood by most participants with firsthand knowledge. Dairymen with operational and non-operational methane digesters did not know what they were getting themselves into, and that a lack of troubleshooting tools and technical support directly contributed to the non-operative status of most shut down systems.

Methane digesters were shown to require more time and knowledge than anecdotal evidence provides to an industry that has traditionally been conservative and which is now evolving rapidly. It is the recommendation of this study is to address underlying issues related to a lack of troubleshooting services available, such as online monitoring and 24 hour tech support.

Any proposal to implement a methane digester should have a plausible comprehensive service agreement, for the life of the machine or system. This may come in the form of a third party service contract or lease agreement between the dairy and an outside digester management company, for the estimated life of the machine.

Technical research on methane digester operations should be ongoing and done in a way to encourage adoption of an innovative waste management system, and then 
secondly as a renewable energy source. In addition, important issues that would need to be addressed in future studies on costs associated with digester system update(s) or repairs including: any and all engine or digester replacement parts, shipping costs, labor costs, an alternate waste management plan for times when the digester is being serviced or updated, should be incorporated into the assessment of any feasibility study, cost benefit analysis or contractual service agreement.

Possible implications of this study point to the emergence of a third party management company market, as a industry service sector that could provide many of the technical and biological competence could contribute to the widespread adoption of methane digesters in California. 


\section{REFERENCES}

Babbie, E. (2007). The Practice of Social Research (12th ed.). Belmont, CA, USA: Wadsworth.

Bilek, A. (2006, July/August). Trading carbon credits from methane digester. 28 (4), p. 16.

Billikopf, G. (2003). Labor Management in Agriculture: Cultivating Personnel Productivity (2nd ed.). Modesto, CA: University of California.

Borjesson, P. (2006). Environmental system analysis of biogas systems-Part 1: Fuel-cycle emissions. Journal of Biomass and Bioenergy, 30 (5), 468-485.

Cady, C. W., \& Francesconi, M. (2010). Water Quality Regulations for Dairy Operators in California's Central Valley-Overview and Compliance Cost Analysis. Sacramento: California Department of Food and Agriculture.

California Department of Food and Agriculture. (2010). California Cost of Production 2010 Annual. California Department of Food and Agriculture. Sacramento: Dairy Marketing Branch.

California Department of Food and Agriculture. (2013). California Cost of Production 2013 Annual. California Department of Food and Agriculture. Sacramento: Dairy Marketing Branch.

California Energy Commission. (2014). Anaerobic Digestion. Retrieved May 2, 2014, from California Energy Commission: http://www.energy.ca.gov/biomass/anaerobic.html

California Public Utilities Commission. (2014). Energy's Electricity and Natural Gas Regulation in California. Retrieved September 4, 2014, from California Public Utilities Commission: http://www.cpuc.ca.gov/puc/

Capper, J. L., Cady, R. A., \& Bauman, D. E. (2009). The Environmental Impact of Dairy Production: 1944 compared with 2007. The Journal of Animal Science , 87, 21602167.

Central Valley Region Water Quatlity Control Board. (2010, 12 14). Confined Animal Facilities. Retrieved August 1, 2014, from Water Issues: http://www.waterboards.ca.gov/centralvalley/water_issues/dairies/ 
Davidsson, A., Jansen, J., Appelqvist, B., Gruvberger, C., \& Hallmer, M. (2007). Anaerobic Digestion Potential of Urban Organic Waste: A Case Study in Malmo, Sweden. Journal of Waste Management and Research (25), 162-169.

Duncan, M. (2004). U.S. Federal Initiatives to Support Biomass Research and Development. Journal of Industrial Ecology , 7 (3-4), 193-201.

Gloy, B. A., \& Dressler, J. B. (2010, August). Financial Barriers to the Adoption of Anaerobic Digestion on US Livestock Operations. Agricultural Finance Review, 70 (2), pp. 157-168.

Howard, W. H., \& MacMillan, R. (1991). In Search of Excellence on the Farm: An Example of Case Research. Agribusiness , 7 (1), 1-10.

Hurley, S., \& Summers, M. (2013). An Economic Analysis of Six Dairy Digester Systems in California. California Energy Commission, Energy Research and Development Division. Summers Consulting, LLC.

Hurley, S., Ahern, J., \& Williams, D.,W. (2007). An Analysis of the Tradeoffs between Policy Instruments to Induce Dairy Producers in California to Participate in a Centralized Digester. Portland: American Agricultural Economics Association.

James, M., Erik, O., William, M., Richard, N., Carmen, S., \& Roberto, M. (2007). Profits, Costs, and the Changing Structure of Dairy Farming. United States Department of Agriculture, Economic Research Service. Washinton D.C.: United States Department of Agriculture.

Key, N., \& Sneeringer, S. (2011). Carbon Emissions, Renewable Electricity and Profits: Comparing Alternative Policies to Promote Anaerobic Digesters on Dairies. American Agricultural Economics Association, Annual Meeting of the AAEA. Pittsburgh: American Agricultural Economics Association.

Key, N., \& Sneeringer, S. (2011). Carbon Markets and Methane Digesters: Potential Implications for the Dairy Sector. Journal of Agricultural and Applied Economics , 4 (43), 569-590.

Key, N., \& Sneeringer, S. (2011). Climate Change Policy and the Adoption of Methane Digesters on Livestock Operations. Economic Research Service. Washington D.C.: United States Department of Agriculture.

Khade, A. S. (1996). An application of benchmarking in the dairy industry. Benchmarking for Quality Management and Technology , 3 (4), 34-41. 
Kramer, J. M. (2004). Agricultural Biogas Casebook - 2004 Update. Madison: Research Strategies Inc.

Krich, K., Augenstein, D., Batmale, J., Benemann, J., Rutledge, B., \& Salour, D. (2005). Biomethane from Dairy Waste, A Sourcebook for the Production and Use of Renewable Natural Gas in California. Western United Dairymen.

Kumar, V., Aaker, D., and Day, G. (2001). Essentials of Marketing Research ( $2^{\text {nd }}$ ed.). New York: John Wiley and Sons Ltd.

Lazarus, W. F. (2008). Farm-Based Anaerobic Digesters as an Energy and Odor Control Technology. United States Department of Agriculture. Washington D.C.: United States Department of Agriculture.

Lehtomaki, A. H. (2007). Laboratory investigations on co-digestion of energy crops and crop residues with cow manure for methane production: Effects of crop to manure ratio. Jounal of Resources, Conservation and Recycling , 51 (3), 591-609.

Lusk, P. (1998). Methane Recovery from Animal Manures The Current Opportunities Casebook. U.S. Department of Energy, National Renewable Energy Laboratory. Washington D.C.: Resource Development Associates.

Madelrieux, S., \& Dedieu, B. (2008). Qualification and Assessment of Work Organisation in Livestock Farms [Electronic Resource]. 2, 435-446.

Mayring, P. (2000). Forum Qualitative Sozialforschung / Forum: Qualitative Social Research. Qualitative Content Analysis , 1 (2).

Meyer, D., \& Powers, T. (2011). Manure Treatment Technologies: Anaerobic Digesters. University of California Agriculture and Natural Resources , 8409.

Miljkovic, D., Shaik, S., \& Braun, D. (2012). Impact of Biofuel Policies on Livestock Production in the United States. Journal of Policy Modeling (34), 817-831.

Morse, D., Guthrie, J. C., \& Mutters, R. (1996). Anaerobic digester survey of California dairy producers. 79, 149-153.

Moser, M. A., Mattocks, R. P., \& Moore, J. A. (2000). Benefits, Costs and Operating Experience at Ten Agricultural Anaerobic Digesters.

Nishio, N. (2007). Recent development of anaerobic digestion process for energy recovery from wastes. Journal of Bioscience and Bioengineering , 103(2), 105112. 
Oladosu, G. (2012). Estimates of the Global Indirect Energy-Use Emission Impacts of USA Biofuel Policy.

Rico, J. G. (2006). Characterisation of solid and liquid fractions of dairy manure with regard to their component distribution and methane porduction. Journal of Bioresource Technology, 98 (5), 971-979.

Sacramento Municipal Utilities District. (2014). Sacramento Municipal Utilities District. Retrieved June 10, 2014, from SMUD's Carbon Offsets Program: https://www.smud.org/en/residential/environment/carbon-offsets.htm

Summers, M., \& Williams, D., W. (2013). An Economic Analysis of Six Dairy Digester Systems in California. California Energy Commission. Vol. 1, Energy Research Development Division. Summers Consulting, LLC.

United States Department of Agriculture, U.S. Environmental Protection Agency, U.S. Department of Energy. (USDA, USEPA, USDOE 2014). "Biogas Opportunities Roadmap: Voluntary Actions to Reduce Methane Emissions and Increase Energy Independence." Washington D.C.: U.S. Department of Agriculture, U.S. Environmental Protection Agency, U.S. Department of Energy.

United States Department of Agriculture. (2010). USDA Dairy Safety Training Guide. Commission on Health and Safety and Workers' Compensation. Davis: University of California .

United States Department of Energy. (USDOE 2014a). Database of State Incentives for Renewables and Efficiency. Retrieved August 31, 2014, from DSIRE's California Incentives/Policies for Renewables \& Efficiency:

http://dsireusa.org/incentives/index.cfm?re $=0 \&$ ee $=0 \&$ spv $=0 \&$ st $=0 \&$ srp $=1 \&$ state $=$ CA

United States Environmental Protection Agency. (2014b). Anaerobic Digester Database. Retrieved January 20, 2014, from EPA AgStar: http://www.epa.gov/agstar/projects/index.html\#database

United States Environmental Protection Agency. (2014c). EPA's AgSTAR News and Events. Retrieved September 8, 2014, from News and Events: http://www.epa.gov/agstar/news-events/digest/2014spring.html\#one

United States Environmental Protection Agency. (2014d). The AgSTAR Program. Retrieved July 15, 2014, from United States Environmental Protection Agency: http://www.epa.gov/agstar/index.html 
Van Dyne, D. L. (1994). Biogas Production from Animal Manures: What is the Potential. USDA, Economic Research Service. Washington D.C.: Industrial Uses of Agricultural Materials Situation and Outlook Report.

Wright, P. (2001). Overview of anaerobic digestion systems for dairy farms.

Yacobucci, B. D. (2012). Biofuel Incentives: A Summary of Federal Programs. Prepared for Members and Committees of Congress. Washington D.C.: Congressional Research Service.

Yvon-Durocher, G., Allen, A., Bastviken, D., Conrad, R., Gudasz, C., St-Pierre, A., Thanh-Duc, N., \& del Giorgio, D.A., (2014). Methane Fluxes Show Consistent Temperature Dependence across Microbial to Ecosystem Scales. Nature 507, 488-491 (27 March 2014) Retrieved from Princton Journal Watch: November 15, 2014. doi: 10.1038/nature13164 


\section{APPENDICES}

\section{A. Interview Discussion Guide}

Note. Time allotted per interview is one hour. $(\mathrm{A})=$ dairies who have previously installed a methane digester, $(\mathrm{B})=$ dairies who have not yet installed a methane digester.

Introductory questions and background. Ice breaker questions:

1. Can you tell me about the history of your dairy? How was it started?

2. How may family members work at your dairy?

3. What is their highest level of education?

Questions related to production:

4. What is your rolling herd average?

5. How much milk does each of your cows produce on average per day?

6. How many acres do you farm and what do you grow?

7. Are you under contract with a processor? If so, for how many years? And can you tell me something of the nature of this relationship?

8. How many seasonal and/or permanent hourly employees do you have?

9. Can you tell how many consultants you contract with and in what areas of production (i.e., vet, nutritionist, etc.)?

Questions related to experience with methane digesters:

10. (A) Which company did you hire to install the digester? (B) Which company are you considering to install the digester? How did you decide on this particular company?

11. (A) What kind of trouble shooting services did they offer? (B) What kind of trouble shooting services do they offer? 
12. (A) How much did it cost to install the digester including direct expenses, labor and equipment? (B) How much will it cost to install the digester (ball park figure)?

13. (A) Were there financial incentives? Did you use grant funding, tax incentives, etc.? (B) What kinds of financial incentives will you consider including grant funding, tax incentives etc.?

14. (A) How long had you considered implementing this technology? (B) How long have you considered implementing this technology?

15. (A) What main factors did you consider most in your decision to install a methane digester? (B) What main factors are you considering most in your decision to install a methane digester?

16. (A) Are you still running the digester? If so, how does the digester fit into your daily operation commitments? (B) How do you see the installation of a digester fitting into your daily operation commitments?

17. (A) How much time per day was/is spent on operating and maintaining this technology? (B) How much time per day do you expect to spend maintaining this technology?

18. (A) Whose primary job is it/was it/ to operate and maintain the digester? How many people besides the primary caretaker are/were/ trained to operate this technology? (B) Whose primary job would it be to operate and maintain the digester? How many people besides the primary caretaker would be trained to operate this technology? 
19. (A) How much training (hours, days) did they receive in how to maintain the digester? (B) How much training (hours, days) do you expect to spend training employees to operate and maintain the digester?

Performance evaluation and expectations:

20. (A) Can you explain the main reason why your expectations were or were not met? (B) Can you explain what your expectations with regard to this technology would be?

21. (A) How has the performance of this technology differed from your initial expectations? (B) What are your initial performance expectations with regard to this technology?

Further insights, suggestions and commentary:

22. (A) Given what you know now, would you have done anything differently?

(B) Given what you know now, what are your predictions for the future of this technology?

23. (A) Can you explain why you would or would not reinvest in this technology again? (B) Can you explain what helped form your opinion of the adoption of methane digesters?

Wrap up:

24. (A) And (B) Do you have any further comments or suggestions? 
B. Description of Planned Procedures

\section{Topic and Hypothesis}

Methane digesters were introduced into California in the 1970's, and were thought to be a good way to address increasing waste management and energy needs. Since that time, many technological advances have been made and numerous papers written and published on the economic feasibility of implementing anaerobic digestion systems on California dairies. However of the approximately 20 anaerobic systems that have been installed on California dairies to date, only $50 \%$ of them are still in use.

My hypothesis is possible human error in the form of lack of training and technical support of the various mechanical and management issues of these systems associated with methane digesters, has directly contributed to the lack of widespread adoption of this technology at the farm level. This is what my data will either prove or disprove.

\section{$\underline{\text { Subjects }}$}

Twelve subjects will be selected to be interviewed for the purpose of this study. The twelve subjects who will participate in the study will fall into one of three categories; dairy producers who have installed an methane digester which is currently operational (n $=4$ ), dairy producers those who have installed an methane digester in the past but is currently non-operational $(\mathrm{n}=4)$, and dairy producers who are planning to install a digester on their farm $(n=4)$. The expected age, gender and ethnicity of the subjects is predominantly male, Caucasian and approximately $30-65$ years of age.

\section{$\underline{\text { Recruitment }}$}

The twelve subjects needed for this study will be identified and recruited through lists available on the USDA's AgStar website, by the University of California Cooperative Extension Dairy Advisors, through discussions with dairymen, and through advising $\mathrm{Cal}$ Poly faculty contacts ${ }^{15}$. Dairies that meet the aforementioned criteria will be contacted first by phone to determine the dairy producers' willingness to participate in the case study, and to schedule a time of their choosing to conduct an in-depth interview at their facility.

\section{Data Collection}

Each interview is to take no more than one hour to complete and will be scheduled at the earliest convenience of the participant. A digital voice recorder will be used to conduct each interview along with a camera for photos of the dairies and written notes taken by the interviewer. Consent for the interview and participation in the study will be obtained at the beginning of each interview with the provided consent form and by recorded verbal acknowledgement. Interviews will be conducted using general open ended questions,

\footnotetext{
${ }^{15}$ Note. Dairy industry contacts to be provided by Dr. Bruce Golden, Dr. Jim Ahern and Dr. Wayne Howard
} 
with attention to that particular dairy. Interviews will be conducted with each dairy over a period of twelve months, from August 2013 to August 2014.

\section{Classification of Data}

The data collected from these interviews will be classified as confidential. During each interview, the participating dairy producers will be asked 24 open-ended questions. These questions are designed to encourage the subject to be as descriptive as possible in their responses, and are designed to allow the producer the opportunity to provide a more accurate or candid picture of the potential effectiveness of methane digesters on California diaries.

\section{Methods to Preserve Data}

After each interview is conducted, transcripts will be made and sent to both the subject and the Cal Poly committee chair faculty member for review, thereby limiting the number of individuals with access to data containing identifiers. Face sheets will be removed containing identifying information from the interview questions, and code numbers will be substituted in for names or other identifiable markers. A list matching the codes with the identity of the subjects will be kept in a secure location separate from the data. In effect, the names of the dairies and those interviewed will be kept confidential and will not be included in the final thesis or published any publication of this study. Upon final completion of the study, all identifiers will be destroyed.

\section{$\underline{\text { Potential Risks to Subjects }}$}

The information to be gathered through face to face interviews with dairy owners or employees who have/had/will have direct contact with an anaerobic digestion system holds no physical or physiological risk, and would be deemed minimal risk to those subjects who participate in this study. Any unforeseen risks associated with the findings or this study will be mitigated with the confidentiality agreement and the methods to ensure preservation of data.

\section{Potential Benefits of Research}

Potential beneficiaries of this research include the agricultural business, dairy management and related fields of study. Further analysis of the qualitative and quantitative data collected could point to other underlying issues related to the management and operation of anaerobic digester technology. 


\section{Consent Form}

INFORMED CONSENT TO PARTICIPATE IN: Barriers to Adoption of Methane Digester Technology on California Dairies.

A research project on Methane Digesters is being conducted by Mrs. Desiree Libarle, a student in the Department of Agricultural Business at Cal Poly, San Luis Obispo. The purpose of the study is to gather firsthand information from dairy producers who have/had firsthand experience with methane digester technology or are considering implementing this technology.

You are being asked to take part in this study by participating in an in-depth interview. Your participation will take approximately one hour. Please be aware that you may omit any questions you prefer not to answer, and you may discontinue your participation at any time without penalty.

There are no known physical or psychological risks associated with participation in this study. However, if you should perceive any associated risks, please be aware that you may contact Mrs. Desiree Libarle by phone 707-291-6980 or by email atdlibarle@gmail.com, or Dr. Wayne Howard at Agribusiness Department, California Polytechnic State University, San Luis Obispo, CA 93407-0254 by phone 805-756-5022 or by email at whhoward@ calpoly.edu for assistance.

Your confidentiality will be protected as the name of yourself and your dairy will be kept confidential and will not be included in the final thesis or released in any publication of this study. In addition, transcripts and any photos taken of your dairy during the following interview will be sent to you and the advising Cal Poly faculty member for review.

Potential benefits associated with the study include a greater understanding of anaerobic technology on California dairy farms by practitioners in the field of agricultural business, dairy management and related fields.

If you have questions regarding this study or would like to be informed of the results when the study is completed, please feel free to contact Mrs. Desiree Libarle at 707-291-6980 or by email at dlibarle@ gmail.com, or Dr. Wayne Howard at 805-7565022 or by email at whhoward@ calpoly.edu. If you have concerns regarding the manner in which the study is conducted, you may contact Dr. Steve Davis, Chair of the Cal Poly Human Subjects Committee, at (805) 756-2754, CA2avis@ calpoly.edu, or Dr. Susan Opava, Dean of Research and Graduate Programs, at (805) 756-1508, sopava@calpoly.edu.

If you agree to voluntarily participate in this research project as described, please 
indicate your agreement by signing below. Please keep one copy of this form for your reference, and thank you for your participation in this research.

Signature of Volunteer

Signature of Researcher

Date 